\title{
Benign Tumours and Pseudotumours Within the Porta Hepatis Masquerading as Perihilar Cholangiocarcinoma
}

\author{
Nezhoubné nádory a pseudotumory v porta hepatis maskující \\ perihilární cholangiokarcinom
}

\author{
Vasiliadis K. ${ }^{1}$, loannidis O. ${ }^{2}$, Tsalis K. ${ }^{2}$ \\ ${ }^{1} 1^{\text {st }}$ Surgical Department, General Hospital Papageorgiou, Thessaloniki, Greece \\ $24^{\text {th }}$ Surgical Department, Medical School, Aristotle University of Thessaloniki, General Hospital George Papanikolaou, Thessaloniki, Greece
}

\begin{abstract}
Summary
Background: Hilar cholangiocarcinoma (HC), also referred to as Altemeier-Klatskin's tumour, is a lethal primary extrahepatic carcinoma of biliary epithelial origin, arising within $2 \mathrm{~cm}$ of the hilar confluence. Radical surgical excision provides the best chance for a cure; however, the management of patients with $\mathrm{HC}$ is challenging not only because of the need for a high level of skill in biliary and hepatic resections, but also because of the difficulty in reaching an accurate diagnosis preoperatively. In fact, the differential diagnosis of $\mathrm{HC}$ is a diagnostic dilemma which is currently persisting, as modern, sophisticated diagnostic modalities are not always able to provide a definitive preoperative diagnosis. This difficulty is compounded by the fact that alternative entities that mimic $\mathrm{HC}$ may be present in up to $25 \%$ of patients with hilar obstruction. This makes precise preoperative characterisation of a hilar stricture extremely important by preventing unnecessary, high-risk, major surgical procedures. Therefore, alternative benign entities masquerading as Altemeier-Klatskin's tumour deserve an important place in the differential diagnosis of hilar obstruction. Purpose: Considering the important clinical implications that a precise diagnosis of the aetiological cause of a biliary obstruction at the liver hilum would have, this paper will focus on the differentiation between $\mathrm{HC}$ and benign hilar obstructions and will review benign tumours and pseudotumours masquerading as $\mathrm{HC}$ along with their specific diagnostic features.
\end{abstract}

\section{Key words}

Altemeier-Klatskin's tumour - hilar biliary stricture - misdiagnosis - benign Altemeier-Klatskin-like lesions - Klatskin-mimicking lesions

\begin{abstract}
Souhrn
Východiska: Hilární cholangiokarcinom (HC) nazývaný také Klatskinův tumor je letální primární extrahepatální karcinom z biliárního epitelu vznikající do $2 \mathrm{~cm}$ od spojení žlučovodů. Nejlepší šanci na vyléčení představuje radikální chirurgická excize. Léčba pacientů s HC je však problematická, a to z důvodu vysokých požadavků na zkušenosti s biliárními a jaterními resekcemi a také proto, že stanovení přesné diagnózy před operací není jednoduché. Diferenciální diagnostika HC představuje diagnostické dilema, nebot' ani moderní, sofistikované diagnostické modality neposkytnou vždy definitivní preoperativní diagnózu. Stavy, které mohou HC mimikovat, jsou navíc př́tomné až u 25 \% pacientů s obstrukcí žlučových cest. Proto je precizní stanovení etiologie zúžení hilu před operací zásadní, aby se předešlo zbytečným, vysoce rizikovým závažným chirurgickým zákrokům. Benigní stavy vydávající se za Klatskinův tumor si v diferenciální diagnostice obstrukce hilu zaslouží své místo. Cíl: Vzhledem k důležitým klinickým implikacím presné diagnózy etiologie obstrukce žlučových cest $v$ jaterním hilu se tento článek zaměřuje na rozlišení $\mathrm{HC}$ a benigních obstrukcí hilu. Bude uveden přehled benigních nádorů a pseudotumorů vydávajících se za $\mathrm{HC}$ společně s jejich charakteristickými diagnostickými znaky.
\end{abstract}

\section{Klíčová slova}

Klatskinův tumor - hilární biliární striktura - nesprávná diagnóza - benigní Klatskinovy léze léze podobné Klatskinovým lézím

\begin{abstract}
The authors declare they have no potential conflicts of interest concerning drugs, products, or services used in the study.

Autor̆i deklarují, že $v$ souvislosti s předmětem studie nemaji žádné komerční zájmy.

The Editorial Board declares that the manuscript met the ICMJE recommendation for biomedical papers.

Redakční rada potvrzuje, že rukopis práce splnil ICMJE kritéria pro publikace zasílané do biomedicínských časopisů.

$\equiv$

Orestis loannidis, MD

$4^{\text {th }}$ Surgical Department

Aristotle University of Thessaloniki

General Hospital George

Papanikolaou

Alexandrou Mihailidi 13

54640 Thessaloniki, Greece

e-mail: telonakos@hotmail.com

Submitted/Obdrženo: 4. 2. 2019

Accepted/Prijato: 4. 9. 2019
\end{abstract}

doi: 10.14735/amko2019411 


\section{Introduction}

Hilar cholangiocarcinoma $(\mathrm{HC})$, also referred to as Altemeier-Klatskin's [1,2] tumour, is a lethal primary extrahepatic carcinoma of biliary epithelial origin, arising within $2 \mathrm{~cm}$ of the hilar confluence. It is the second most common primary hepatic malignancy, comprising $10-25 \%$ of primary hepatic malignancies worldwide, and accounts for about $50-70 \%$ of all HCs [3,4]. Radical surgical excision of $\mathrm{HC}$ provides the best chance for a cure. However, the infiltrative nature and anatomic location of the tumour necessitates early diagnosis on one hand and on the other, major and challenging procedures that combine bile duct resection with hepatectomy, caudate lobectomy and/or portal vein resection, aiming at complete tumour clearance, which however entails significant morbidity [5]. Equally challenging in the management of patients with hilar biliary obstruction is the establishment of a definitive preoperative diagnosis. In fact, the differential diagnosis of $\mathrm{HC}$ remains a diagnostic dilemma, including a significant number of other primary malignancies, metastatic disease and benign lesions [6].

Painless jaundice with evidence of biliary obstruction is the usual clinical pattern of biliary tumours, which usually raises a strong clinical suspicion of biliary neoplasia [7]. Unfortunately, clinical and laboratory parameters related to the diagnostic work-up of obstructive jaundice are non-specific in identifying the precise nature of its underlying cause. This diagnostic dilemma is currently persisting, as modern, sophisticated imaging modalities are not always able to provide a definitive diagnosis [8].

The difficulty in establishing a definitive diagnosis in patients with biliary obstruction at the liver hilum is further compounded by the fact that alternative entities that mimic $\mathrm{HC}$ may be present in up to $25 \%$ of patients with hilar obstruction $[9,10]$. Biopsies and/or cytology are often nondiagnostic [11], because while both intraductal biopsies and biliary brush cytology have a very high specificity of $99.2 \%$ and $99 \%$, respectively, the sensitivity is low $(48.1 \%$ and $45 \%$ respectively); however a combination of both techniques can enhance the sensitivity up to $59.4 \%$, which is still far lower than the ideal [12]. Imaging features, although specific, cannot always definitively exclude the presence of a malignancy [9]. On the other hand, it is well documented that over $80 \%$ of hilar biliary strictures in patients with no history of previous surgery are secondary to malignancy [9]. Therefore, it is rather reasonable to consider a hilar stricture as malignant in nature until proven otherwise [13]. Despite this concept, it has to be accepted that a diagnosis based on indirect evidence would be incorrect on occasion. Notwithstanding this, a $25 \%$ rate of false diagnosis especially in complicated case of hilar obstruction is significantly high, higher than most would have expected and higher than most would have considered as occasional. In fact, according to the results of a recent large series of patients with hilar strictures, approximately $16 \%$ of patients with hilar strictures and a preoperative diagnosis of $\mathrm{HC}$ proved to have a benign disease $[9,10,13-17]$. This rate of false diagnosis cannot be overlooked, especially when misdiagnosis leads to unnecessary, high-risk surgical procedures. Therefore, alternative pathologic benign entities masquerading as Altemeier-Klatskin's tumour in terms of clinical presentation and imaging features deserve an important place in the differential diagnosis of hilar obstruction. Whereas a malignancy requires major resections or preoperative chemoradiation followed by liver transplantation in highly selected patients [5], benign conditions usually do not require major interventions, and can usually be successfully treated with percutaneous balloon dilation [18] or endoscopic or percutaneous stent placement, in which case a biodegradable stent may be used [19].

Considering the important clinical implications that a precise diagnosis of the aetiological cause of biliary obstruction at the liver hilum would have, this paper will focus on the differentiation between $\mathrm{HC}$ and benign hilar obstructions and will review benign tumours and pseudotumours masquerading as $\mathrm{HC}$ along with their specific diagnostic features.

\section{Differentiation between $\mathrm{HC}$ and benign biliary obstruction within the porta hepatis}

Hilar cholangiocarcinoma occurs most commonly during the $6^{\text {th }}$ decade of life [20] whereas a younger age favours benign causes of biliary hilar strictures. Patients with $\mathrm{HC}$ usually present with jaundice, abdominal discomfort and anorexia [21]. Weakness, nausea, weight loss and signs of obstructive jaundice such as pruritus, dark urine and claycoloured stools are often present [22]. Primary sclerosing cholangitis (PSC), inflammatory bowel disease, intrahepatic stones and oriental cholangiohepatitis are among the commonly encountered comorbidities that constitute additional risk factors for the development of HC [23].

Unfortunately, both benign and malignant biliary strictures share, in general, the same clinical symptoms and signs, while bilirubin and serum tumour markers such as CA19-9, IL-6 and neutrophil gelatinase associated lipocalin do not have the power to reliably differentiate the malignant from the benign nature of a biliary stricture [10]. This notwithstanding, a detailed evaluation of the current symptoms and surgical history are of great importance in the diagnostic work-up of patients with biliary obstruction at the liver hilum. In fact, the clinical symptoms and signs associated with serum liver enzymes and tumour markers initially contribute to the establishment of a working diagnosis. Furthermore, painless progressive jaundice combined with anorexia and weight loss favour malignancy, whereas previous biliary surgery is a significant factor that favours benignity [24]. In parallel, malignant hilar lesions often cause complete biliary obstruction, therefore patients tend to have higher levels of bilirubin and alkaline phosphatase [25].

Imaging investigations remain the cornerstone for the evaluation of the underlying cause of biliary obstruction at the liver hilum. Duplex ultrasonography (DUS) may directly depict a bile duct mass. In a series of 429 patients with obstructive jaundice, the sensitivity and specificity of DUS in localising the biliary obstruction were $94 \%$ and $96 \%$, respec- 
tively [26]. Furthermore, in a study by Hann et al., DUS depicted the HC in $87 \%$ of patients. Of which as intra-ductal polypoid masses in $18 \%$, as infiltrative lesions in $26 \%$ and as nodular mural thickening in 56\% [27]. Recently, contrast-enhanced ultrasound based on the enhancement patterns of lesions has shown promising results in the diagnosis and differential diagnosis of HC [28]. Despite these facts, the true role of contrast-enhanced ultrasound in the differential diagnosis of hilar biliary strictures remains undefined. Additionally, the sensitivity, specificity and accuracy of DUS are operator-dependent and there are no data supporting its role in the differential diagnosis of hilar biliary strictures. Consequently, other imaging investigations are usually needed to better clarify the exact nature of a hilar lesion.

Triple-phase, high-resolution multidetector-row computed tomography (CT) scanning plays a key role in the diagnosis of $\mathrm{HC}$. According to its macroscopic type, HC appears on CT as a hyperattenuating intra-ductal mass, focal mural thickening or lumen obliteration at the hilar bile duct. Its sensitivity reaches up to $90-100 \%$ with an accuracy of $92.3-95 \%[29,30]$. It can also help differentiate between benign and malignant strictures at the liver hilum. Vascular involvement, infiltration of second-order bile ducts, duct wall thickness $>4 \mathrm{~mm}$ and lobar atrophy are all indicators for cholangiocarcinoma [31]. In a study by Saluja et al., CT scanning had a sensitivity, specificity, positive predictive value, negative predictive value and diagnostic accuracy of 79.2, 79.4, 73.1, 84.4 and $79.3 \%$, respectively, for predicting the nature of the biliary stricture at the liver hilum [15]. Rösch et al. [32] reported that the presence of a mass and lymph node enlargement $>1 \mathrm{~cm}$ are significant imaging features $(p<0.001$ and 0.009 , respectively) in determining the malignant nature of a hilar stricture. In addition, Choi et al. [33] in their retrospective analysis reported that biliary wall thickening $>1.5 \mathrm{~mm}$ suggestive of a mass, rim-like contrast enhancement in either the arterial or portal phase, long stricture, higher proximal dilatation and lymph node enlargement $>1 \mathrm{~cm}$ were significant multiphasic spiral CT findings favouring malignancy. CT scanning is also useful in detecting other malignant lesions and to evaluate alterations in the hepatic parenchyma, such as lobar atrophy, and to assess the possibility of lymph node involvement and distant metastases. CT is also useful in detecting liver and peritoneal metastases [30].

Attempting to preoperatively establish a definite tissue diagnosis and eliminate the potential to falsely conclude a benign disease, CT-guided percutaneous biopsy (fine-needle aspiration (FNA) or core needle biopsy) of a hilar lesion has been proposed as an alternative method, which may improve diagnostic sensitivity. However, this approach is technically demanding, is feasible only in patients with a depicted focal mass, and is associated with serious complications such as the risk of peritoneal seeding of cancerous cells [34]. Despite the controversy regarding the true incidence of needle-tract seeding [35], it is currently recommended to avoid biopsy of a presumed $\mathrm{HC}$ because of the risk of complications such as tumour seeding or bleeding [34].

Similar to CT scanning, magnetic resonance imaging (MRI) in combination with magnetic resonance cholangiopancreatography (MRCP) is an excellent diagnostic tool for the diagnosis of $\mathrm{HC}$. It provides valuable information regarding biliary ductal involvement, vascular invasion, hepatic lobar atrophy, lymph node involvement and distant metastases [36]. HC appears as a hypointense signal on $\mathrm{T} 1$ weighted images and high signal intensity of T2 imaging. The tumour generally appears to be hypovascular in relation to the adjacent hepatic parenchyma and may be characterised by irregular thickening of the bile duct wall with upstream dilation of intrahepatic bile ducts while MRCP enables reconstruction of the biliary network which can define the longitudinal, intraductal tumour extension with an accuracy reaching 71-96\% [37]. The reported sensitivity and specificity of MRCP for the detection of bile duct malignancy are 81 and 100\%, respectively [38]. Saluja et al. [15] reported that MRCP demonstrated with an accuracy of $100 \%$ the level of obstruction in patients with HC. In the same study, it was found that MRCP combined with MRI had a sensitivity of $87.5 \%$, a specificity of $85.3 \%$, a positive predictive value of $80.8 \%$, a negative predictive value of $90.6 \%$ and a diagnostic accuracy of $82.7 \%$ in predicting the nature of the stricture. However, the sensitivity of MRI-MRCP in differentiating benign from malignant strictures varies widely, from 30 to $98 \%[39,40]$. Park et al. [41] reported $81 \%$ sensitivity, $70 \%$ specificity and $76 \%$ accuracy of MRI-MRCP in differentiating malignant from benign strictures. The currently accepted MRI-MRCP criteria favouring malignant over benign hilar strictures are: irregular margin of the stricture combined with asymmetric dilatation of the biliary radicles, extended/long length stricture with abrupt tapering and the presence of a mass $[15,42]$. Unfortunately, CT scanning and MRI-MRCP do not allow for invasive procedures such as biopsy, biliary drainage or stent insertion; therefore, direct cholangiography is usually needed in the differential diagnosis of biliary stricture at the hilum of the liver.

The role of positron emission tomography/computed tomography (PET/CT) in the differential diagnosis of hilar strictures remains unclear. It has a reported specificity of over $80 \%$ in detecting distant metastases, but it seemingly does not have much use in differentiating hilar strictures [43]. Studies utilising PET/CTs are limited and more studies are needed to further evaluate the benefit of this imaging modality in differentiating hilar biliary strictures.

Percutaneous transhepatic cholangiography (PTC) and endoscopic retrograde cholangiopancreatography (ERCP) are commonly used direct cholangiographic methods for the diagnosis of $\mathrm{HC}$ and the differential diagnosis of biliary strictures at the liver hilum. They provide a clear delineation of the biliary tree and depict precisely the location and extent of the 3 biliary obstruction. Abrupt, irregular and eccentric biliary stenosis with concomitant dilatation of the proximal biliary tree are the main features that imply malignancy. The sensitivity, specificity and accuracy of ERCP/PTC for the 
diagnosis of malignant biliary obstruction are $58-85 \%, 70-75 \%$ and $72-81 \%$, respectively $[32,41]$. A significant limitation of these techniques is their invasiveness, which is associated with the risk of serious complications [29]. In particular, the PTC-related mortality ranges between 0.6 and 5.6\% [42]. Another limitation of ERCP/PTC is their failure to depict the whole biliary tree in the event of complete biliary obstruction. In such cases, neither method can precisely estimate the characteristic features of a biliary stricture. On the other hand, these methods can be applied for biliary drainage as well as for material sampling for brush cytology and forceps biopsy or molecular analysis, which may accomplish a definitive diagnosis. However, both cytology and biopsy have a low sensitivity for $\mathrm{HC}$ ranging between 41 and $50 \%$ for brush cytology $[16,44]$, and $53 \%$ for forceps biopsy [44], since cancerous tissue is mainly located in the fibrous stroma surrounding the bile ducts [45].

In patients with presumed $\mathrm{HC}$, who have had a negative brush cytology or forceps biopsy, endoscopic ultrasonography-guided fine needle aspiration (endoscopic ultrasound (EUS)-guided FNA) and intraductal ultrasonography (IDUS) represent the currently available alternative modalities to provide a precise diagnosis. According to the results of two small series of patients endoscopic EUS-guided FNA was found to have a sensitivity of $77-89 \%$ and a specificity of $100 \%$ for the diagnosis of HC. Unfortunately, in the same studies EUS-guided FNA was found to have $29 \%$ negative predictive value, implying that a negative for malignancy EUS-guided FNA cytology does not definitely exclude $H C[46,47]$. One other limitation of EUS-guided FNA is the significant concern over seeding the FNA tract with malignant cells, especially in patients with proximal biliary strictures. Therefore, it is currently recommended to avoid EUS-guided FNA in a presumed surgically curable $\mathrm{HC}$ because of the risk of tumour seeding [34]. On the other hand, IDUS providing highresolution images of the ductal wall and periductal tissues has shown promising results in differentiating malignant from benign biliary strictures by depicting the heterogeneity and irregularity of bile duct thickening and the invasion of neighbouring hilar structures [48]. Furthermore, the combination of IDUS with ERCP improved the diagnostic accuracy over that of either ERCP or MRCP alone ( 88 vs. $76 \%$ and $58 \%$, respectively) [49]. Meister et al., after retrospectively reviewing 397 patients with undefined biliary strictures who had undergone ERCP with IDUS, found IDUS to have a sensitivity, specificity and accuracy of $97.6,98$ and $92 \%$, respectively [50]. A bile duct wall thickness of $<7 \mathrm{~mm}$ and absence of external compression depicted at IDUS are the basic imaging characteristics of benign strictures that have a negative predictive value of $100 \%$ for excluding malignancy in patients with biliary obstruction seen on cross-sectional imaging without a mass [51].

Direct peroral cholangioscopy has recently attracted renewed interest because of the low sensitivity of the currently used laboratory, radiological, and endoscopic work-up in succeeding a definitive diagnosis of the underlying aetiology of biliary strictures, the opportunity to perform visual-guided biopsies of suspicious intraluminal biliary lesions and mainly because of the development of a single-operator cholangioscopy (SOC) system, SpyGlass TM Direct Visualization System or simply SpyGlass (Boston Scientific, Natick, MA, USA), which overcomes the technical difficulties related to the use of mother-baby endoscopes $[52,53]$. In a multicentre international study, SOC was performed with an overall success rate of $89 \%$ and a 30 day complication rate of $7.5 \%$. Its overall sensitivity and specificity for differentiating malignant and benign ductal lesions were $78 \%$ and $82 \%$, respectively, higher than the $51 \%$ and $54 \%$ of ERCP alone. The sensitivity of the pathology of samples obtained by SOC was only $49 \%$ for the definite diagnosis of malignant disease [52]. In a similar study, Fukuda et al., after combining peroral cholangioscopy with ERCP, reported a sensitivity of $100 \%$, a specificity of $87.5 \%$ and an accuracy of $93.5 \%$ for differentiating malignant from benign ductal lesions [54]. Although the advantages of peroral cholangioscopy have been confirmed it is not widely used, mainly because of the high cost, time associated with the procedure, and the significant risk of cholangitis [55].

When attempting to establish a definitive tissue diagnosis of a hilar lesion it should be remembered that HCs are usually small, hard to access, sclerosing lesions containing a small number of carcinoid cells. These features of $\mathrm{HC}$ explain the high percentage of false negative results of brush cytology/biopsy studies. Therefore, several sophisticated cytological techniques have been introduced recently to improve the sensitivity of cytological studies in biliary cancer detection, including fluorescence in situ hybridisation and digitised image analysis. The first method detects cancer cells with the use of fluorescent probes which identify chromosomal polysomy, while the second uses special stains to detect cancer cells and to quantitate nuclear DNA and identify aneuploidy [29]. Kipp et al. [56] demonstrated that fluorescence in situ hybridisation markedly improved the sensitivity of brush cytology in patients with undefined biliary strictures; however, with no significant difference in specificity. In another study by Baron et al. [57] it was shown that digitised image analysis also significantly improved the sensitivity, but it simultaneously impaired the specificity when compared with routine brush cytology. Although promising, the usefulness of these methods for the definite diagnosis of $\mathrm{HC}$ still needs further evaluation. Finally, analysis of the DNA methylation status of some important genes in the exfoliated cells of the bile may also contribute in the near future in establishing the diagnosis of $\mathrm{HC}$ in patients with biliary strictures. In a recent study, Yin et al. [58] found that the methylation status of the P16 and adenomatous polyposis coli (APC) gene promoters in the bile aspirate was valuable in the diagnosis of malignant biliary obstruction. Differentiation between $\mathrm{HC}$ and alternative benign entities within the porta hepatis is also difficult to assess intraoperatively. This is because a frozen section analysis of a small amount of a suspicious tissue obtained intraoperatively from 
the liver hilum is often of limited value, due to the fact that well-differentiated cholangiocarcinomas are extremely difficult to differentiate from benign lesions.

\section{Benign lesions within the porta hepatis masquerading as HC Benign tumours}

Benign tumours of the extrahepatic bile ducts are exceedingly rare, being less common than traumatic and non-traumatic inflammatory lesions [59]. They account for only $6 \%$ of all biliary tumours and $0.1 \%$ of all biliary tract operations [60]. Benign tumours usually develop from the epithelial or nonepithelial layers of the bile ducts, giving rise to a spectrum of clinical, pathologic and radiologic features [61]. The majority of these neoplasms fall into the category of polyps, papillomas and adenomas. The remainder comprise cystadenomas, adenomyomas, granular cell myoblastomas, fibromas, leiomyomas, neurinomas, hamaratomas, lipomas, melanomas and carcinoids [62]. Despite their rarity, these tumours should always be included in the differential diagnosis of biliary strictures.

Benign biliary tumours exhibit, in general, similar clinical symptoms and signs with malignant lesions with the exception of anorexia and weight loss, which are rarely present in patients with benign lesions [63]. This notwithstanding, no clinical symptom or sign is specific enough to accurately differentiate benign neoplasms from malignant or inflammatory pseudotumours. Benign neoplasms of the extrahepatic bile ducts are usually diagnosed on final pathologic examination of the surgical specimen.

\section{Epithelial tumours}

\section{Extrahepatic biliary adenomas}

Extrahepatic biliary adenomas arise from the glandular epithelium lining the bile ducts, representing the most common type of benign tumour of the extrahepatic biliary tree. According to the World Health Organization (WHO) classification of benign biliary tumours, three forms of biliary adenomas are recognised: tubular, papillary and tubulopapil- lary [61]. Their incidence is very low, and only a limited number of biopsy-proven cases have been reported to date in English-language literature [59,64,65].

In the majority of patients with symptomatic biliary adenomas, obstructive jaundice comprises the prevalent presenting clinical sign [66]. However, biliary obstruction is usually transitory and may be confused with biliary lithiasis. Biliary adenomas are usually localised in the distal part of the common bile duct and biliopancreatic ampulla, with lesions in the common hepatic duct and hepatic ducts accounting for only 15 and $8 \%$, respectively [67]. Regardless of various hypotheses such as focal, reactive process to injury, hepatolithiasis and clonorchis infection, their exact pathogenetic mechanism remains undefined [68].

Their imaging features provided by US, CT or MRI-MRCP are not specific enough to differentiate them accurately from HC. Correct diagnosis of these lesions may be provided by ERCP combined with multiple tissue biopsies [69]. This is because brush cytology, having a low sensitivity, is an inadequate test making histology necessary to establish a firm diagnosis.

Given their rarity and the limited understanding of their natural progression, several authors argue that the use of a conservative approach would be more appropriate for biliary adenomas $[69,70]$. However, the difficulty in establishing a firm preoperative diagnosis combined with the risk of recurrence in cases of partial tumour resection and their malignant potential rationalises the current strategy of most hepatopancretobiliary surgeons, who advocate radical resection of the adenoma-bearing duct [64]. Following this strategy, distal lesions would require pancreaticoduodenectomy, and proximal lesions, hepatic resection with biliary reconstruction.

\section{Intraductal papillary neoplasms of the bile duct}

Intraductal papillary neoplasms of the bile duct (IPNB) is a recently recognised rare type of epithelial bile duct tumour with an exophytic nature, exhibiting a papillary or villous growth within the bile duct lumen. It has been adopted as a distinct clinical and pathologic entity in the WHO classification of 2010 and is classified into IPN with low-or intermediate-grade intraepithelial neoplasia, IPN with high-grade intraepithelial neoplasia and IPN with an associated invasive carcinoma [71]. These tumours represent the biliary counterpart of intraductal papillary mucinous neoplasm of the pancreas (IPMN) and can develop anywhere along the biliary ducts, occasionally causing duct dilatation. Hypersecretion of mucin can also be encountered [72].

Microscopically, these tumours are composed of papillary fronds with fine vascular cores. Their neoplastic epithelial cells usually display atypia, which ranges from borderline to marked, and can be associated with invasive carcinoma. Based on these microscopic features, IPNBs are considered as premalignant lesions towards invasive cholangiocarcinoma.

According to their histomorphology and immunophenotypical profile, these neoplasms are further classified into four subtypes: pancreato-biliary, intestinal, gastric and oncocytic, with pancreatobiliary being the most common [73]. The intestinal and pancreatobiliary types are frequently malignant and therefore are regarded as counterparts of the main duct-type IPMN. Immunopathologically, IPNBs frequently express MUC2, MUC5AC and cytokeratin 20, which are the mucous phenotypes of the intestinal and gastric crypt epithelium [74].

Prior to IPNB inclusion into the WHO classification of tumours, various terminology has been used to describe the types of tumours currently included in the spectrum of IPNBs, such as biliary papilloma/papillomatosis, papillary carcinoma of the extrahepatic bile duct, and biliary cystadenoma and cystadenocarcinoma. According to the latest WHO classification of tumours of the digestive system, types of intrahepatic cholangiocarcinoma with intraductal growth and papillary carcinoma of the extrahepatic bile ducts are currently exclusively included in IPNBs in cases where their intraductal component is composed of 
papillary fronds with fine vascular cores. In addition, cystic biliary tumours previously included in the type of cystadenoma or cystadenocarcinoma are currently considered as a cystic variant of IPNB in case of bile duct communication and the absence of ovarian-like stroma [75].

The pathogenesis of IPNBs is not clear. Studies from the Far East suggest an association between IPNBs and hepatolithiasis or clonorchiasis infection. However, this association has not been confirmed in Western studies [76]. Genetic tests of patients with IPNBs suggest a stepwise progression from an initially low-grade intraductal papillary dysplasia to, finally, an invasive adenocarcinoma which is promoted mainly by KRAS mutation and loss of p16 [70]. However, the pathogenesis of these tumours remains practically undefined and more studies are needed to clarify and interpret the spectrum of molecular and genetic changes leading to the development of IPNBs.

As a newly defined entity, the clinical and pathologic features of IPNBs are still ill-defined, making their diagnosis challenging. In fact, the most common clinical signs in patients with IPNBs are nonspecific, including intermittent abdominal pain, jaundice and acute cholangitis, while up to $5 \%$ of patients can be asymptomatic [76].

The location of IPNBs varies. Some reports demonstrated that IPNBs are mainly located at the intrahepatic bile ducts $[77,78]$ whereas others found that the hepatic hilum was the most common location [76].

The most common imaging finding of IPNBs are bile duct dilatation and intraductal masses, which can be depicted by US, CT and MRI-MRCP, having, however, varying sensitivity $[79,80]$. Duodenoscopy can show a patulous orifice of the duodenal papilla draining mucin while endoscopic retrograde cholangiography can detect diffuse dilatation of the bile ducts with amorphous filling defect(s) as a result of mucobilia that is present in nearly two-thirds of patients with IPNBs [81]. Retrograde cholangiography can also provide a definitive diagnosis when combined with tissue bio- psies. Similarly, cholangioscopy can histopathologically confirm the diagnosis, also providing the ability to assess the spreading of the tumour along the epithelium of the biliary ducts [72].

Despite the fact that IPNBs are considered as premalignant lesions, their management should be similar to that applied for cholangiocarcinomas, meaning that radical surgical intervention is required, including major hepatectomy, with or without extrahepatic bile duct resection or pancreaticoduodenectomy. This policy is justified by the fact that preoperative diagnosis usually underestimates the degree of tumour cell atypia [72]. Nevertheless, in cases of preoperative precise diagnosis of IPNB with low- to high-grade intraepithelial neoplasia and limited superficial tumour extension, limited surgical intervention may be justified [82].

\section{Non-epithelial tumours}

\section{Granular cell tumour}

Granular cell tumours are benign, extremely rare neoplasms usually occurring in the oral cavity and subcutaneous tissue. Fewer than $1 \%$ of these tumours arise in the extrahepatic biliary tree [83]. In 1952, Coggins et al. [84] reported the first case of a granular cell tumour of the biliary tract. To date, no case of a malignant bile duct granular cell tumour has been reported. Most authors accept the theory that these tumours originate from Schwann cells, on the basis of histological, electron microscopic and immunohistichemical features [85].

The majority of patients with bile duct granular cell tumours are black, young and female. In fact, the tumour's prevalence is four times greater in women. Clinical symptoms and signs are nonspecific including jaundice, abdominal pain and pruritus. Their size at the time of diagnosis ranges from $0.5 \mathrm{~cm}$ [86] to $4.0 \mathrm{~cm}$ [87] while in $11.6 \%$ of cases the tumour is located near the confluence of the right and left hepatic ducts, masquerading as $\mathrm{HC}$. A definitive preoperative diagnosis, although difficult, might be provided from several repeated biopsies. The histopathology of a granular cell tumour involves large, granular-like eosinophilic cells which are often immunoreactive for the S-100 protein [88]. However, even if it is precisely diagnosed preoperatively, a surgical operation may be considered, to decidedly rule out malignancy and definitively treat symptoms and signs caused by the obstructing lesion.

\section{Neural tumours}

\section{Neurofibroma}

Neurofibromas are rare benign tumours arising from Schwann cells that form the myelin sheath of the peripheral nerves. Occasionally, these tumours occur as solitary lesions, but usually they develop in the context of neurofibromatosis type I (von Recklinghausen's disease), which is an autosomal dominant disease associated with multiple tumours of the nervous system, with or without skin lesions. Extrahepatic bile duct neurofibromas are extremely rare, with only a limited number of cases reported in medical literature [89-91]. These tumours grow on the connective tissue nerve sheath of the sympathetic and parasympathetic nerves that innervate the bile ducts. Long spindle cells characterise these tumours pathologically. The neurogenic features of long spindle cells are demonstrated by positive immunohistochemistry for $\mathrm{S100,}$ which is a marker for neuron intermediate filament protein.

In the absence of Recklinghausen's phakomatosis, the majority of extrahepatic bile duct neurofibromas are secondary to inappropriate intraoperative bile duct injuries, where epineurium trauma triggers a reactive fibroinflammatory disorganised regeneration process [89]. Common bile duct primary solitary neurofibromas can also develop secondary to chronic inflammation, biliary lithiasis or infection, when disorganised regeneration of injured nerve axons is enclosed by the nerve's intact epineurium.

Clinical symptoms and signs are nonspecific and there have been no specific detective indexes or imaging features reported for this tumour in the literature $[92,93]$. Therefore, differentiation from other biliary lesions and establishing a definite preoperative diagnosis is extremely difficult. Despite their rarity, bile duct neurofibromas should be 
considered in patients with a history of previous biliary trauma. Exploratory laparotomy is usually indicated and intraoperative frozen section examination should guide the type and extent of the procedure.

\section{Schwannoma}

Schwannoma or neurilemoma is a benign tumour derived from Schwann cells, which form the inner portion of the peripheral nerve sheaths. It is usually located in the upper extremities, trunk, head and neck, retroperitoneum, mediastinum, pelvis and peritoneum [94]. Peripheral nerve schwannomas can be associated with neurofibromatosis type I and II [95]. Digestive tract schwannomas are relatively rare, commonly arising in the stomach, large bowel, rectum and oesophagus [96]. Very rarely, these tumours can develop along the sympathetic and parasympathetic network of nerve fibres overlying the biliary duct wall [97]. Extrahepatic biliary schwannomas tend to develop in adults in the fifth decade of life, with a female predominance. Obstructive jaundice is the most common clinical sign, followed by abdominal pain and weight loss; however, the clinical symptoms and signs are nonspecific and there are no specific parameters or imaging findings for these tumours [98].

Macroscopically, schwannomas are usually encapsulated solid globular or ovoid tumours while microscopically these tumours consist of two distinct components, a hypercellular and a myxoid [99].

Immunohistochemistry is necessary to distinguish schwannomas from neurofibromas and other digestive stromal neoplasms. Specifically, schwannomas are strongly positive for vimentin and S100 protein but they are negative for muscle cell markers and CD117, which in turn are positive in smooth muscle and gastrointestinal stromal tumours. Additionally, digestive tract schwannomas are in the majority of cases negative for CD34 [100].

Although there may be a preoperative suspicion, a definitive diagnosis of this exceedingly rare extrahepatic biliary neoplasm requires histopatho- logical confirmation. Therefore, and despite the considerable chance of serious postoperative complications, most hepatopancreatobiliary surgeons agree that surgical resection is the treatment of choice [101]. Following surgical treatment digestive tract schwannomas have an excellent prognosis [101].

\section{Neuroendocrine tumours - bile duct carcinoid}

Neuroendocrine tumours (NETs) are a distinct, heterogeneous group of neoplasms that exhibit characteristic clinical, histological and biological properties. They arise from various neuroendocrine cells which are physiologically involved in the neuroendocrine interface. Commonly, NETs develop in the appendix, bronchus, ileum and rectum, possibly arising from embryonic neural crest cells (Kultschitsky cells) [102]. However, this type of cell is exceedingly scarce throughout the bile duct epithelium, accounting for the fact that extrahepatic bile duct NETs are very rare [103]. In fact, according to the study by Modlin et al., among digestive system NETs, the incidence of extrahepatic bile duct NETs was found to be $0.32 \%$ [104].

The term carcinoid was used until recently to describe these tumours; however, in 1996 the WHO proposed the broader term of neuroendocrine tumours to define these neoplasms [105]. According to the WHO the term NETs includes all endocrine tumours, ranging from well-differentiated carcinoid tumours to poorly differentiated cancers. The staging of NETs is based on size, number of mitoses per high power field (HPF), invasiveness and on the Ki-67 immunostaning (cellular marker for proliferation) to differentiate their grade and malignant potential. The latest WHO classification adds emphasis to the NETs grade $(G)$, distinguishing these tumours into three categories, which were assigned as follows: NET G1 or carcinoid, with a mitotic count of $<2$ per $10 \mathrm{HPF}$ and/or a Ki-67 index $\leq 2 \%$; NET G2, with a mitotic count of 2 to 20 per $10 \mathrm{HPF}$ and/or a Ki-67 index of 3-20\%; and G3 (neuroendocrine carcinoma), with a mitotic count of $>20$ per $10 \mathrm{HPF}$ and/or a Ki-67 index > 20\% [106].
Carcinoid (NET G1) tumours of the extrahepatic biliary ducts account for only $0.1-0.2 \%$ of all carcinoids of the digestive system [13]. They occur more frequently in young female patients [107]. To date, only 14 patients with hilar NET $\mathrm{G} 1$ have been reported in international literature [108].

Various hypotheses have been proposed for the development of extrahepatic biliary NETs, however their actual pathogenesis remains largely unsettled. The most accepted theory regarding their pathogenesis is based on the assumption that these neoplasms originate from a multipotent stem cell which has the ability to differentiate into a NET [109]. The rationale of this theory is supported by the fact that NETs exhibit mixed phenotypes, ranging from actual NETs to true carcinomas with dispersed neuroendocrine cells [110]. Intestinal metaplasia consequently to chronic inflammation increasing the number of embryonic neural crest cells throughout the biliary tract epithelium is also implicated in the pathogenesis of biliary NETs. [111].

Biliary NETs usually occur during the $6^{\text {th }}$ decade of life and their most frequent anatomic location is the common bile duct (58\%) followed by the hilar confluence $(28 \%)$, the cystic duct ( $11 \%)$ and the hepatic duct (3\%) [104]. In the majority of cases biliary NETs are non-functioning without evidence of systemic endocrine manifestations. Occasionally, they can be hormonally active with a detectable specific serum or urine marker indicative of the endocrine nature of the tumour $[112,113]$. The size of biliary NET G1 tumours at the time of diagnosis is rather small, ranging from 1.1 to $5.5 \mathrm{~cm}$ while their symptoms and signs such as abdominal discomfort, jaundice, weight loss and back pain are non-specific and develop as a result of either obstruction/invasion or metastases [114,115].

Imaging modalities such as US, CT or MRI-MRCP are not specific enough to firmly diagnose biliary NETs. Precise preoperative diagnosis of extrahepatic biliary NETs is difficult and is usually reached postoperatively by the histopathologic examination of the surgical specimen. Occasionally, a de- 
finitive preoperative diagnosis might be provided from repeated cytological samplings or from several repeated biopsies [116,117].

Appropriate management for biliary G1 NETs necessitates surgical resection with negative margins combined with hepatoduodenal, periportal and pericholedochal lymph node clearance $[114,118]$. These tumours are of low malignant potential and therefore, a favourable prognosis should be expected following appropriate surgical management [119].

\section{Pseudotumours}

\section{Inflammatory pseudotumours}

Inflammatory pseudotumours (IPTs) (plasma cell granulomas, inflammatory myofibroblastic tumours) are rare idiopathic benign lesions consisting of localised proliferation of a heterogeneous population of inflammatory cells (spindle cells, plasma cells, lymphocytes, eosinophils and neutrophils) together with myofibroblastic proliferation and areas of fibrosis and/or necrosis [120,121]. These tumours can arise in practically every site in the body, however the lungs, omentum and mesentery represent the most common locations [122]. Primary sclerosing cholangitis, Crohn's disease and phlebitis have been associated with the development of IPTs [123,124].

Despite the fact that the exact incidence of extrahepatic biliary IPTs is practically unknown, it has been reported that approximately $4-20 \%$ of bile duct strictures correspond to IPTs $[125,126]$. The aetiology of IPTs remains uncertain. Among various proposed pathogenetic hypotheses, the most likely are antecedent bacterial, parasitic or viral infection. Actually, there is an established association between Epstein-Barr virus infection and IPT development, in view of the fact that the Epstein-Barr virus has often been found in histopathological IPTs samples [127]. With regard to the pathogenesis of extrahepatic biliary IPTs, it has been argued that they may develop as a result of recurrent episodes of acute cholangitis, secondary to portal venous infection and obliterating phlebitis $[128,129]$. Furthermore, associations between IPTs and recurrent pyogenic cholangitis (RPC) leading to the formation of biliary strictures have been described [120]. Another proposed IPT aetiology is autoimmunogenic processes, given that some cases have responded well to corticosteroid treatment [130]. The latter aetiology is supported by the fact that IgG4-related IPTs of the liver developed in patients with autoimmune pancreatitis [131].

Clinical findings in patients with biliary IPTs are non-specific, being indistinguishable from those of HC. On imaging, IPTs appear as focal masses that may show delayed and persistent enhancement owing to their fibrous content On cholangiography IPTs are depicted as biliary strictures of intra- or extrahepatic biliary ducts. These imaging findings are remarkably similar to those of HC [132]. In addition, preoperative tumour sampling is technically challenging and it usually results in suboptimal diagnosis [133]. Notwithstanding this, distinction between IPTs and malignant lesions is crucial, because IPTs have a benign biological behaviour and are characterised by the property of spontaneous regression [134].

Surgical resection or bypass operations are indicated for the management of biliary IPTs ensuring a satisfactory prognosis, provided that the tumour has been proved clearly benign. The probability of IPTs in patients undergoing surgical exploration should always be considered and the extent of the resection should be determined by the intraoperative findings and fast frozen section analysis [135].

\section{Dominant stricture in the context of PSC}

Primary sclerosing cholangitis is a chronic cholestatic liver and biliary tract disorder of possible autoimmune pathogenesis, characterised by a highly variable natural history [136]. The disease is complicated by a fibrotic process that results in strictures involving intra- and extrahepatic bile ducts [136]. Its diagnosis is currently based on direct cholangiographic or MRCP findings, which include discontinuous focal stricturing and saccular dilatation of bile ducts, which progressively create a 'beaded' appearance $[137,138]$.
PSC consists in a diagnosis of exclusion which is based on cholangiographic biliary alterations which cannot be ascribed to another cause. Accordingly, PSC diagnosis can be established only in the absence of various underlying pathogenic processes, which can lead to the typical PSC imaging pattern [139].

Differential diagnosis of PSC includes several disorders that can cause similar biliary alterations such as bacterial cholangitis, intra-arterial administration of floxuridine, prior biliary surgery and AIDS related cholangiopathy. Central to the diagnosis of PSC is the fact that the disease is associated with inflammatory bowel disease in up to $80 \%$ of patients [139].

PSC may run a long asymptomatic course but it may also have an aggressive progression, complicated with recurrent biliary tract obstruction/cholangitis leading to end-stage liver disease. In up to $20 \%$ of PSC patients, a localised high-grade bile duct stricture at the liver hilum may be the presenting feature mimicking $\mathrm{HC}$ [140]. This finding should be interpreted in light of the fact that PSC is the most common predisposing condition for $\mathrm{HC}$ in the Western world, inducing a lifetime risk for the development of $\mathrm{HC}$ of $25 \%$. Moreover, approximately $75 \%$ of PSC patients who develop $\mathrm{HC}$ have a dominant biliary stricture, and compared to sporadic cases of HC, PSC patients tend to present the tumour earlier, in the $4^{\text {th }}$ or $5^{\text {th }}$ decade of life $[140,141]$. Furthermore, the incidence of $\mathrm{HC}$ peaks in the first 2 years following PSC diagnosis, while the risk of carcinogenesis is not associated with the duration of the underlying inflammatory process [142]. Of note is that the pool data of patients with benign lesions obstructing the common bile duct with an initially presumed diagnosis of $\mathrm{HC}$ demonstrated a $1.6 \%$ definitive diagnosis of PSC at the final histopathologic examination $[10,13,14,17]$.

The development of $\mathrm{HC}$ is a lethal sequel of PSC, therefore evaluation of biliary strictures discovered in PSC patients is of the utmost importance. Nevertheless, early and accurate diagnosis of $\mathrm{HC}$ in the setting of PSC remains 
an unresolved diagnostic challenge. Among the various modern diagnostic tools available, per oral cholangioscopy, which allows direct endoluminal biliary visualisation and directed biopsies of suspicious strictures is probably the method of choice as it provides over $90 \%$ sensitivity and specificity for the diagnosis of HC [143]. Unfortunately, $\mathrm{HC}$ is still diagnosed at an advanced stage which is associated with a dismal survival. Except palliative treatment no other option is available [144].

The surgical management of PSC with presumed $\mathrm{HC}$ deserves special consideration, including resection versus liver transplantation. The choice of treatment should be guided on one hand by the clinical stage of $\mathrm{HC}$ and on the other by the severity of PSC. Patients with advanced $\mathrm{HC}$ stage or metastatic disease are poor candidates for surgical therapy. Conversely, patients with early stage $\mathrm{HC}$ and satisfactory liver function are good candidates for surgical resection [139]. In highly selected PSC patients with nonmetastatic and limitedearly stage $H C$, liver transplantation following radiochemotherapy is a very promising treatment option in experienced centres [145].

\section{Recurrent pyogenic cholangitis}

Recurrent pyogenic cholangitis (oriental cholangiohepatitis) is a condition characterised by recurrent episodes of bacterial cholangitis associated with intrahepatic strictures and hepatolithiasis, commonly affecting individuals from Southeast Asia $[146,147]$. The disease peaks between the $3^{\text {rd }}$ and $5^{\text {th }}$ decades of life, with no gender preference, and is characterised by the presence of pigmented biliary stones, which are typically located in the left lateral and right posterior biliary ducts. Patients commonly present with the classical but non-specific features of pyogenic cholangitis [148].

The pathogenesis of hepatolithiasis is driven by a complex interplay between metabolic disorders, reduced bile flow rate, bile stasis, infection, and chronic infestation of the biliary tree, all interacting in a vicious circle. In fact, liver flukes and ascaris are believed to initially induce biliary injury promoted by stone formation and strictures followed by bacterial superinfection [149]. Another hypothesis regarding RPC pathogenesis holds that Escherichia Coli infection interacting with hypoproteinaemia promotes bilirubin deconjugation in the bile ducts inducing the formation of biliary sludge and stones [150]. Sepsis induced by recurrent bacterial cholangitis is the major cause of lethality in patients with RPC. Additionally, RPC is associated with the development of $\mathrm{HC}$ in approximately $10 \%$ of patients [150].

Apart from intrahepatic stones, the typical imaging features of RPC are biliary strictures, ductal wall thickening, central duct dilatation with abrupt tapering (arrowhead sign), poor delineation of bile duct branching and non-filling of segmental biliary ducts [151]. Bile duct wall thickening and enhancement at the liver hilum depicted at imaging in patients with RPC can be misinterpreted as HC. This is due to the fact that conventional imaging studies alone cannot accurately differentiate a RPC hilar stricture from HC [152].

Planning treatment of RPC complicated with $\mathrm{HC}$ requires careful judgement, taking into consideration both disease processes. The type of surgical operation should be guided on one hand by the $\mathrm{HC}$ clinical stage and on the other by the location of intrahepatic stones, the present of additional biliary strictures and coexistent parenchymal liver atrophy [153].

\section{Portal biliopathy}

Portal biliopathy $(\mathrm{PB})$ is recently introduced terminology referring to the morphologic alterations of the entire extra and intrahepatic biliary tree in patients with portal hypertension (PH) [154]. $\mathrm{PH}$, especially when it is caused by chronic thrombotic obstruction of the extrahepatic portal vein, is commonly followed by the development of an abnormal periportal and pericholedochal bridging variceal network forming the portal cavernoma, in an attempt to drain the extrahepatic portal system towards the systemic circulation [155-157]. Less common causes of PB include liver cirrhosis, portal vein fibrosis without cirrhosis and congenital hepatic fibrosis [155].
Portal cavernoma exerts extrinsic pressure on the adjacent biliary ducts so that the epicholedochal venous plexus of Saint and paracholedochal venous plexus of Petren may on one hand mechanically protrude into the bile duct lumen and on the other, induce secondary ischaemic vascular bile duct injury with or without cholangitis [156]. These latter secondary events are believed to lead to the development of irregular strictures of both extra and intrahepatic bile ducts (segmental dilated segments with a beaded appearance, ectasia and 'pruning' of the intrahepatic bile ducts) that can cause asymptomatic cholestasis in more than $50 \%$ of patients and rarely, symptomatic biliary obstruction [158]. Several studies suggest that the prevalence of PB secondary to portal cavernoma can range from 80 to $93 \%[158,159]$. Notwithstanding this, PB is a very rare and usually asymptomatic entity [160].

Upper quadrant pain typically of biliary origin, recurrent fever with chills and jaundice alone or in combination suggest the possibility of symptomatic PB in patients with PH. Direct cholangiographic findings include segmental upstream dilation, calibre irregularity, filling defects that may be interpreted as common bile duct calculi, stricture and extrinsic impression on the bile duct due to collaterals [161]. Clinical symptoms and signs and cholangiographic alterations of PB may resemble $\mathrm{HC}$, with the portal cavernoma appearing as a solid mass which is termed 'pseudocholangiocarcinoma sign' raising serious diagnostic and therapeutic issues [162].

\section{Mirizzi syndrome}

Mirizzi syndrome, first described by Pablo Luis Mirizzi in 1948 [163] and which since then has come to bear his name, refers to secondary common bile or hepatic duct obstruction caused by an extrinsic compression from an impacted stone in the Hartmann's pouch of the gallbladder or the cystic duct. Its current definition includes four variations: a) the cystic duct runs parallel to the common hepatic at the gallbladder infundibulum; b) impacted biliary stone in the cystic duct or the infundibulum of the 
Tab. 1. Diagnostic criteria of IgG4-SC177.

\section{Features}

bile duct histology

bile duct imaging

serology

polyorganic involvement

steroid-responsive disease

\section{Characteristic criterion}

lymphoplasmacytic infiltrate with > 10 IgG4-positive cells/HPF within and around bile ducts with associated obliterative phlebitis and storiform fibrosis

a) single or multiple strictures involving intrahepatic, proximal extrahepatic, or intrapancreatic bile ducts; b) fleeting/migrating biliary strictures

increased serum levels of IgG4

pancreas, retroperitoneal fibrosis, renal lesion, and salivary/lacrimal gland

normalization of liver enzymes or resolution of stricture (radiologically)

lgG4 - immunoglobulin G4, HPF - high power field

gallbladder; c) obstruction of the common hepatic duct either by a biliary stone or by secondary inflammation; and d) obstructive jaundice associated with recurrent cholangitis or secondary biliary cirrhosis [164-166]. Csendes et al. [164] in 1989 further defined four evolving stages of the syndrome, from extrinsic compression to fistulisation and/or complete erosion of the common hepatic duct.

The clinical presentation of the syndrome varies from no symptoms or signs to severe acute cholangitis. Despite recent advances in medical technology, preoperative diagnosis of Mirizzi syndrome is usually challenging. This is due to the fact that the clinical picture, laboratory values and imaging findings are not specific [167]. Furthermore, the syndrome is associated with portal inflammation, which often results in the development of biliary stricture mimicking the periductal infiltrating type of $\mathrm{HC}$ [31] and apart from masquerading as $\mathrm{HC}$, it is associated with an increased risk of gallbladder cancer, as compared to patients with uncomplicated cholelithiasis [168]. MRCP is the method of choice as it commonly depicts the impacted gallstone and the concomitant extrinsic compression that exerts on the extrahepatic ducts in addition to the dilatation of the proximal biliary ducts, which are all typical imaging findings in favour of Mirizzi syndrome [31].

IgG4 related sclerosing cholangitis in the context of IgG4-related disease

Immunoglobulin G4-related sclerosing cholangitis (IgG4-SC) is the biliary manifestation of the recently recognised IgG4-related disease (IgG4-RD), which is a multisystemic disorder often associated with autoimmune pancreatitis (AIP) $[169,170]$. Usually, lgG4-RD involves multiple organs causing lgG4-related sclerosing pancreatitis, cholangitis, retroperitoneal fibrosis, sialadenitis, asymptomatic lymphadenopathy, thyroiditis, nephritis, pneumonia, prostatitis and some IPTs [171]. These disease entities belong in the lgG4-RD spectrum with commonly overlapping clinical and radiological features [172].

Immunoglobulin G4-RDs are distinguished by an elevated serum IgG4, extensive lgG4-positive plasma cells and T-lymphocyte infiltration in the affected organs and response to steroid therapy. They affect mainly middle-aged/older men (60 years of age) who commonly present with mass-forming lesions suspicious of malignancy $[173,174]$. Clinical presentation depends on the organ involved, while general symptoms and signs such as fever and weight loss are present in fewer than $10 \%$ of the patients [174].

The pathogenesis of IgG4-RD remains undetermined, but there is evidence supporting the role of autoimmunity and allergy. Inflammation and subsequent fibrosis in IgG4-RD is possibly driven by $T$ helper 2 cells and regulatory T cells [175]. Allergy has been proposed as an additional pathogenetic mechanism because of the significant overlap of symptoms and concomitant atopic disorders [176]. The exact role of IgG4 in the pathogenesis of IgG4-RD remains unclear and the question as to whether the increased T-lymphocyte infiltration of the affected organs is a primary or a secondary event remains unanswered.

The diagnosis of IgG4-RD is currently based on the international consensus diagnostic criteria [177]. The Mayo Clinic HISORt, which is a mnemonic that stands for histology, imaging, serology, other organ involvement and response to therapy criteria, were initially proposed for the diagnosis of AIP [178]. The three histological cornerstones supporting the diagnosis of IgG4-RD are an lgG4-positive lymphoplasmacytic tissue infiltrate, storiform fibrosis and obliterative phlebitis. Tissue eosinophilia of the involved organs may also coexist. Another central unifying characteristic is the response to immunosuppression, particularly steroid therapy (Tab. 1) [179].

Immunoglobulin G4-SC is the most common extrapancreatic manifestation of AIP [180]. It has a male predominance presenting usually in the $5^{\text {th }}$ and $6^{\text {th }}$ decades of life. Its clinical picture is non-specific including obstructive jaundice, weight loss, abdominal pain, steatorrhoea and new onset diabetes [181]. It may be diagnosed incidentally in patients presenting clinically with AIP without clinical symptoms or suspicion of biliary involvement [182].

The diagnosis of IgG4-SC requires a high index of clinical suspicion and can be based on the HISORt criteria [183] and the Japanese IgG4-SC working group statement allowing for differentiation from HC [184]. CT is an invaluable diagnostic method as it demon- 
strates biliary strictures with associated wall thickening and inflammation. Additionally, it can identify the involvement of other organs and generalised lymphadenopathy [185]. Endoscopic retrograde or magnetic resonance cholangiography plays a central role in IgG4-SC diagnosis. Cholangiography depicts diffuse bile duct wall thickening in stenotic segments. These findings may be multiple, showing an intrahepatic distribution similar to that of PSC or they may be located in the hilar plate mimicking $\mathrm{HC}$. The intrapancreatic part of the common bile duct is the most commonly involved site, especially when combined with AIP [186]. Notwithstanding this, these findings are non-specific so that the imaging studies presently employed are unable to differentiate IgG4-SC from HC [187]. Differential diagnoses also include PSC, pancreatic cancer and traumatic biliary strictures. Of note is that, despite the fact that the elevation of serum IgG4 (>140 g/L) is a hallmark of lgG4-SC, it is not regarded as pathognomonic, as nearly $30 \%$ of IgG4-SC patients have normal serum IgG4 levels, while additional, certain PSC cases, and other disease entities might demonstrate high serum IgG4 $[188,189]$. Hypergammaglobulinaemia, hyper lgG, antinuclear antibody, rheumatoid factor and peripheral eosinophilia are additional sensitive serological markers, however their diagnostic value is rather limited because of their low specificity [190]. Occasionally, IgG4-SC can develop as an isolated biliary disease presenting as either a diffuse SC or a hilar IPT [191]. Salivary and/or lacrimal gland swelling added by retroperitoneal fibrosis and renal lesions may coexist on presentation [192].

Accurate diagnosis of IgG4-SC requires histological analysis. Bile duct biopsy revealing more than 10 lgG4-positive plasma cells is considered as the diagnostic threshold [190]. Most IgG4-SC patients respond well initially to glucocorticoid therapy, but refractory or recurrent disease is not uncommon [193]. If such a situation occurs, agents with corticosteroid sparing properties and targeting therapy with the monoclonal antibody rituximab against the surface protein CD20 of B cells may be considered as alternative regimens [181]. However, it should be remembered that when managing a presumed steroid-responsive disease, the use of glucocorticoids must be justified, to avoid the lethal pitfall of missing the correct diagnosis and delaying the treatment of a malignant disease.

\section{Hepatobiliary sarcoidosis}

Sarcoidosis is a chronic multisystem granulomatous disorder of undefined aetiology, which is histologically characterised by non-necrotising granulomas composed of epitheliod cells [194]. The disease occurs mainly in the age group of 20- to 40-year-olds who most commonly develop pulmonary infiltrates and bilateral pulmonary hilar adenopathy [195]. Diagnosis can be established clinically by the involvement of at least two organs and by the presence of a compatible illness that presents with respiratory symptoms. A firm diagnosis can be made only by the demonstration of non-caseating epithelioid cell granulomas on pathological examination of the affected organs.

Hepatobiliary involvement is a rather frequent extrapulmonary site of the disease, affecting more than $50 \%$ of sarcoidosis patients, however it is usually asymptomatic. Only $5-15 \%$ of patients with biopsy-proven hepatobiliary involvement exhibit symptoms and signs of the disease. Rarely, the disorder is associated with severe liver diseases and/or $\mathrm{PH}$ [196]. Isolated liver involvement has been documented in about $13 \%$ of patients with systemic sarcoidosis [197].

Hepatobiliary sarcoidosis (HS) is characterised by the development of multifocal micronodular or macronodular granulomas, which can cause presinusoidal $\mathrm{PH}$ rapidly progressing to liver fibrosis and gradual destruction of the intralobular bile ducts leading to biliary strictures and ductopenia. These derangements can lead to granulomatous cholangitis, which is characterised by a slow onset and can progress in the long term to biliary cirrhosis $[31,198]$. Extra-hepatic biliary tract involvement is rare and is usually caused by extrinsic compression or direct invasion of the portal or peri-portal lymph nodes by the sarcoid granulomas [199]. In such cases, the imaging findings are usually indistinguishable from those of HC [200]. Differentiation from $\mathrm{HC}$ can become even more challenging in cases of isolated HS with no hepatic or pulmonary manifestations or systemic symptoms [201].

The treatment of HS is the same as for systemic sarcoidosis. Once a firm diagnosis of HS is established, decompression of the biliary system must be provided and a long-lasting remission will be required. Importantly, although steroid treatment improves liver function tests it has no effect on the natural course of granulomas [201].

\section{Xanthogranulomatous cholecystitis and choledochitis}

Xanthogranulomatous cholecystitis is an unusual variant of chronic cholecystitis characterised by severe inflammation associated with multiple intramural nodular formation, proliferative fibrosis and foamy histiocytes [202]. It occurs mainly in patients with gallstone disease and its incidence ranges from 1 to $13 \%$ with a slight female predominance [203].

Gallbladder lithiasis, bile retention and chronic inflammation are among the basic causative factors of the disease [204]. The destructive inflammatory process develops mainly in the gallbladder wall, however it is characterised by local invasiveness and fistulisation involving occasionally neighbouring structures exhibiting a 'pseudomalignant' behaviour. Xanthogranulomatous inflammatory involvement of the extrahepatic bile ducts can cause xanthogranulomatous choledochitis, which is characterised by biliary obstruction with inflammatory strictures and hilar lymphadenopathy, features that mimic HC. On extremely rare occasions, xanthogranulomatous choledochitis may develop regardless of the presence of xanthogranulomatous cholecystitis and/or direct fistulisation [126,205]. Xanthogranulomatous choledochitis should be included in the differential diagnosis of patients with a biliary stricture, especially in geographical areas with a high incidence of xanthogranulomatous cholecystitis. However, modern preoperative diagnostic tools are unreliable 
both in confirming the diagnosis and in ruling out malignancy in cases of xanthogranulomatous choledochitis, therefore surgical resection should be performed wherever feasible [205].

\section{Conclusions}

Acknowledging the lack of a diagnostic gold standard that would always allow a firm preoperative diagnosis of $\mathrm{HC}$, it can be concluded that the stakes remain very high when trying to define the exact nature of the underlying aetiology of a hilar stricture/lesion, both because of the potential risk to falsely conclude a benign disease, missing the window of opportunity to radically resect a lethal but potentially curable cancer and because of the economic costs and significant morbidity associated with inappropriate major operations in patients with benign aetiologies. It appears that an individualised and multidisciplinary approach can play a major role in successfully overcoming this diagnostic and therapeutic challenge.

\section{References}

1. Altemeier WA, Gall EA, Zinninger MM et al. Sclerosing carcinoma of the major intrahepatic bile ducts. Arch Surg 1957; 75(3): 450-460.

2. Klatskin G. Adenocarcinoma of the hepatic duct at its bifurcation within the porta hepatis. Am J Med 1965; 38: 241-256. doi: 10.1016/0002-9343(65)90178-6.

3. Gatto M, Bragazzi MC, Semeraro R et al. Cholangiocarcinoma: update and future perspectives. Dig Liver Dis 2010; 42(4): 253-260. doi: 10.1016/j.dld.2009.12.008.

4. Khan SA, Thomas HC, Davidson BR et al. Cholangiocarcinoma. Lancet 2005; 366(9493): 1303-1314. doi: 10.1016/S0140-6736(05)67530-7.

5. Ito F, Cho CS, Rikkers LF et al. Hilar cholangiocarcinoma: current management. Ann Surg 2009; 250(2): 210-218. doi: 10.1097/SLA.0b013e3181afe0ab.

6. Hadjis NS, Collier NA, Blumgart LH. Malignant masquerade at the hilum of the liver. Br J Surg 1985; 72(8): 659-661. doi: 10.1002/bjs.1800720826.

7. Eliason SC, Grosso LE. Primary biliary malignant lymphoma clinically mimicking cholangiocarcinoma: a case report and review of the literature. Ann Diagn Pathol 2001; 5(1): 25-33. doi: 10.1053/adpa.2001.21483.

8. Principe A, Ercolani G, Bassi F et al. Diagnostic dilemmas in biliary strictures mimicking cholangiocarcinoma. Hepatogastroenterology 2003; 50(53): 1246-1249.

9. Gerhards MF, Vos P, van GulikTM et al. Incidence of benign lesions in patients resected for suspicious hilar obstruction. Br J Surg 2001; 88(1): 48-51. doi: 10.1046/j.13652168.2001.01607.x

10. Koea J, Holden A, Chau Ket al. Differential diagnosis of stenosing lesions at the hepatic hilus. World J Surg 2004; 28(5): 466-470. doi: 10.1007/s00268-004-7034-z.

11. Harell GS, Anderson MF, Berry PF. Cytologic bile examination in the diagnosis of biliary duct neoplastic strictures. Am J Roentgenol 1981; 137(6): 1123-1126. doi: 10.2214/ajr.137.6.1123.
12. Navaneethan U, Njei B, Lourdusamy V et al. Comparative effectiveness of biliary brush cytology and intraductal biopsy for detection of malignant biliary strictures: a systematic review and meta-analysis. Gastrointest Endosc 2015; 81(1): 168-176. doi: 10.1016/i.gie.2014.09.017.

13. Are C, Gonen M, D'Angelica M et al. Differential diag nosis of proximal biliary obstruction. Surgery 2006; 140(5) 756-763. doi: 10.1016/j.surg.2006.03.028.

14. Uhlmann D, Wiedmann M, Schmidt F et al. Management and outcome in patients with Klatskin-mimicking lesions of the biliary tree. J Gastrointest Surg 2006; 10(8): 1144-1150. doi: 10.1016/j.gassur.2006.04.003.

15. Saluja SS, Sharma R, Pal S et al. Differentiation between benign and malignant hilar obstructions using laboratory and radiological investigations: a prospective study. HPB 2007; 9(5): 373-382. doi: 10.1080/13651820701504 207

16. Kloek JJ, van Delden OM, Erdogan D et al. Differentiation of malignant and benign proximal bile duct strictures: the diagnostic dilemma. World J Gastroentero 2008; 14(32): 5032-5038. doi: 10.3748/wjg.14.5032.

17. Erdogan D, Kloek JJ, ten Kate FJ et al. Immunoglobulin G4-related sclerosing cholangitis in patients resected fo presumed malignant bile duct strictures. Br J Surg 2008; 95(6): 727-734. doi: 10.1002/bjs.6057.

18. Altman A, Zangan SM. Benign biliary strictures. Semin Intervent Radiol 2016; 33(4): 297-306. doi 10.1055/s-0036-1592325

19. Siiki A, Sand J, Laukkarinen J. A systematic review of biodegradable biliary stents: promising biocompatibility without stent removal. Eur J Gastroenterol Hepatol 2018 30(8): 813-818. doi: 10.1097/MEG.0000000000001167.

20. Cho MS, Kim SH, Park SW et al. Surgical outcomes and predicting factors of curative resection in patients with hilar cholangiocarcinoma: 10-year single-institution experience. J Gastrointest Surg 2012; 16(9): 1672-1679. doi: 10.1007/s11605-012-1960-0.

21. Nuzzo G, Giuliante F, Ardito F et al. Improvement in perioperative and long-term outcome after surgical treatment of hilar cholangiocarcinoma: results of an Italian multicenter analysis of 440 patients. Arch Surg 2012 147(1): 26-34. doi: 10.1001/archsurg.2011.771.

22. Saxena A, Chua TC, Chu FC et al. Improved outcomes after aggressive surgical resection of hilar cholangiocarcinoma: a critical analysis of recurrence and survival. Am J Surg 2011; 202(3): 310-320. doi: 10.1016/j.amjsurg.2010.08.041

23. Zheng-Rong L, Hai-Bo Y, Xin C et al. Resection and drainage of hilar cholangiocarcinoma: an 11-year experience of a single center in mainland China. Am Surg 2011:77(5): 627-633.

24. Paritpokee N, Tangkijvanich P, Teerasaksilp S et al. Fas liver alkaline phosphatase isoenzyme in diagnosis of malignant biliary obstruction. J Med Assoc Thai 1999; 82(12): 1241-1246.

25. Bain VG, Abraham N, Jhangri GS et al. Prospective study of biliary strictures to determine the predictors of malignancy. Can J Gastroenterol 2000; 14(5): 397-402. doi: 10.1155/2000/467567.

26. Sharma MP, Ahuja V. Aetiological spectrum of obstruc tive jaundice and diagnostic ability of ultrasonography: a clinician's perspective. Trop Gastroenterol 1999; 20(4): 167-169.

27. Hann LE, Greatrex KV, Bach AM et al. Cholangio carcinoma at the hepatic hilus: sonographic findings. AJR Am J Roentgenol 1997; 168(4): 985-989. doi: 10.2214/ajr.168.4.9124155

28. Xu HX, Chen LD, Xie XY et al. Enhancement pattern of hilar cholangiocarcinoma: contrast-enhanced ul trasound versus contrastenhanced computed tomography. Eur J Radiol 2010; 75(2): 197-202. doi: 10.1016/ j.ejrad.2009.04.060

29. Aljiffry M, Walsh MJ, Molinari M. Advances in diagnosis, treatment and palliation of cholangiocarci- noma: 1990-2009. World J Gastroenterol 2009; 15(34): 4240-4262. doi: 10.3748/wjg.15.4240

30. Akamatsu N, Sugawara Y, Osada H et al. Diagnostic accuracy of multidetector-row computed tomography for hilar cholangiocarcinoma. J Gastroenterol Hepatol 2010; 25(4): 731-737. doi: 10.1111/j.1440-1746.2009.06113.x. 31. Menias CO, Surabhi VR, Prasad SR et al. Mimics of cholangiocarcinoma: spectrum of disease. Radiographics 2008; 28(4): 1115-1129. doi: 10.1148/rg.284075148. 32. Rösch T, Meining A, Fruhmorgen $S$ et al. A prospective comparison of diagnostic accuracy of ERCP, MRCP, CT, and EUS in biliary strictures. Gastrointest Endosc 2002; 5(7): 870-876. doi: 10.1067/mge.2002.124206.

33. Choi SH, Han JK, Lee JM et al. Differentiating malignant from benign common bile duct stricture with multiphasic helical CT. Radiology 2005; 236(1): 178-183. doi: 10.1148/radiol.2361040792.

34. Heimbach JK, Sanchez W, Rosen CB et al. Trans-peritoneal fine needle aspiration biopsy of hilar cholangiocarcinoma is associated with disease dissemination. HBP (Oxford) 2011; 13(5): 356-360. doi: 10.1111/j.14772574.2011.00298.x

35. Silva MA, Hegab B, Hyde C et al. Needle track seeding following biopsy of liver lesions in the diagnosis of hepatocellular cancer: a systematic review and meta-analysis. Gut 2008; 57(11): 1592-1596. doi: 10.1136/gut.2008.149062.

36. Soares KC, Kamel I, Cosgrove DP et al. Hilar cholangiocarcinoma: diagnosis, treatment options, and management. Hepatobiliary Surg Nutr 2014; 3(1): 18-34. doi: 10.3978/j.issn.2304-3881.2014.02.05.

37. Choi JY, Kim MJ, Lee JM et al. Hilar cholangiocarcinoma: role of preoperative imaging with sonography, MDCT, MRI, and direct cholangiography. AJR Am J Roentgenol 2008; 191(5): 1448-1457. doi: 10.2214/AJR.07.3992. 38. Szklaruk J, Tamm E, Charnsangavej C. Preoperative imaging of biliary tract cancers. Surg Oncol Clin N Am 2002: 11(4): 865-876.

39. Kim MJ, Mitchell DG, Ito Ket al. Biliary dilation differentiation of benign from malignant causes: value of adding conventional MR imaging to MR cholangiopancreatography. Radiology 2000; 214(1): 173-181. doi: 10.1148/radiology.214.1.r00ja35173.

40. Lee MG, Lee HJ, Kim MH et al. Extrahepatic biliary diseases: 3D MR cholangiopancreatography compared with endoscopic retrograde cholangiopancreatography. Radiology 1997; 202(3): 663-669. doi: 10.1148/radiology.202.3.9051013.

41. Park MS, Kim TK, Kim KW et al. Differentiation of extrahepatic bile duct cholangiocarcinoma from benign stricture: findings at MRCP versus ERCP. Radiology 2004; 233(1): 234-240. doi: 10.1148/radiol.2331031446.

42. Weber A, Schmid RM, Prinz C. Diagnostic approaches for cholangiocarcinoma. World J Gastroenterol 2008; 14(26): 4131-4136. doi: 10.3748/wjg.14.4131.

43. Li J, Kuehl H, Grabellus F et al. Preoperative assessment of hilar cholangiocarcinoma by dual-modality PET/CT. J Surg Oncol 2008; 98(6): 438-443. doi: 10.1002/jso.21136. 44. Weber A, von Weyhern C, Fend F et al. Endoscopic transpapillary brush cytology and forceps biopsy in patients with hilar cholangiocarcinoma. World J Gastroenterol 2008; 14(7): 1097-1101. doi: 10.3748/wjg.14.1097. 45. Lazaridis KN, Gores GJ. Cholangiocarcinoma. Gastroenterology 2005; 128(6): 1655-1667. doi: 10.1053/j.gastro.2005.03.040.

46. Fritscher-Ravens A, Broering DC, Knoefel WT et al. EUSguided fi ne-needle aspiration of suspected hilar cholangiocarcinoma in potentially operable patients with negative brush cytology. Am J Gastroenterol 2004; 99(1): 45-51.

47. DeWitt J, Misra VL, Leblanc JK et al. EUS-guided FNA of proximal biliary strictures after negative ERCP brush cytology results. Gastrointest Endosc 2006; 64(3): 325-333. doi: 10.1016/j.gie.2005.11.064 
48. Levy MJ, Vazquez-Sequeiros E, Wiersema MJ. Evaluation of the pancreaticobiliary ductal systems by intraductal US. Gastrointest Endosc 2002; 55(3): 397-408. doi: 10.1067/mge.2002.121878

49. Domagk D, Wessling J, Reimer P et al. Endoscopic retrograde cholangiopancreatography, intraductal ultrasonography, and magnetic resonance cholangiopancreatography in bile duct strictures: a prospective comparison of imaging diagnostics with histopathological correlation. Am J Gastroenterol 2004; 99(9): 1684-1689. doi: 10.1111/j.1572-0241.2004.30347.x.

50. Meister T, Heinzow HS, Woestmeyer C et al. Intraductal ultrasound substantiates diagnostics of bile duct strictures of uncertain etiology. World I Gastroenterol 2013; 19(6): 874-881. doi: 10.3748/wjg.v19.16.874

51. Krishna NB, Saripalli S, Safdar R et al. Intraductal US in evaluation of biliary strictures without a mass lesion on CT scan or magnetic resonance imaging: significance of focal wall thickening and extrinsic compression at the stricture site. Gastrointest Endosc 2007; 66(1): 90-96. doi: 10.1016/j.gie.2006.10.020.

52. Chen YK, Parsi MA, Binmoeller KF et al. Single-operator cholangioscopy in patients requiring evaluation of bile duct disease or therapy of biliary stones. Gastrointest Endosc 2011; 74(4): 805-814. doi: 10.1016/j.gie.2011.04.016. 53. Rösch W, Koch H. Peroral cholangioscopy in choledochoduodenostomy-patients using the pediatric fiberscope. Endoscopy 1978; 10(3): 195-198. doi: 10.1055/s-0028-1098293.

54. Fukuda Y, Tsuyuguchi T, Sakai Y et al. Diagnostic utility of peroral cholangioscopy for various bile-duct lesions. Gastrointest Endosc 2005; 62(3): 374-382. doi: 10.1016/ j.gie.2005.04.032

55. Meining A, Chen YK, Pleskow D et al. Direct visualization of indeterminate pancreaticobiliary strictures with probe-based confocal laser endomicroscopy: a multicenter experience. Gastrointest Endosc 2011; 74(5): 961-968. doi: 10.1016/j.gie.2011.05.009.

56. Kipp BR, Stadheim LM, Halling SA et al. A comparison of routine cytology and fluorescence in situ hybridization for the detection of malignant bile duct stric tures. Am J Gastroenterol 2004; 99(9): 1675-1681. doi: 10.1111/j.1572-0241.2004.30281x.

57. Baron TH, Harewood GC, Rumalla A et al. A prospective comparison of digital image analysis and routine cytology for the identification of malignancy in biliary tract strictures. Clin Gastroenterol Hepatol 2004; 2(3): 214-219. 58. Yin XY, Yan G, Peng JX et al. The clinical values of methylation status of P16, APC genes in bile in diagnosis of malignant obstructive jaundice. p. 91. ASCO Gastrointestinal Cancer Symposium Proceedings. San Francisco, California, USA 2011.

59. Burhans R, Myers RT. Benign neoplasms of the extrahepatic biliary ducts. Am Surg 1971; 37(3): 161-166.

60. Linehan DC, Jarnagin WR, Blumgart LH. Benign tumours and pseudotumours of the biliary tract. In: Blumgart LH (ed.). Surgery of the liver, biliary tract and pancreas. Philadelphia: Saunders 2007: 751-763.

61. Bosman FT, Carneiro F, Hruban RH et al. Tumours of the gallbladder and extrahepatic bile ducts. In: WHO Classification of tumors. 4th ed. IARC press 2012: 263-278. 62. Aggarwal S, Kumar S, Kumar A et al. Extra hepatic bile duct adenoma in a patient with a choledochal cyst. J Gastroenterol Hepatol 2003; 18(3): 351-352. doi: 10.1046/j.1440-1746.2003.02916.x.

63. Sundeep S, Sharma R, Pal S et al. Differentiation between benign and malignant hilar obstructions using laboratory and radiological investigations: a prospective study. HPB (Oxford) 2007; 9(5): 373-382. doi: 10.1080/13651820701504207.

64. Fletcher ND, Wise PE, Sharp KW. Common bile duct papillary adenoma causing obstructive jaundice: case report and review of the literature. Am Surg 2004; 70(5): 448-452.
65. Morris-Stiff GJ, Senda Y, Verbeke CS et al. Papillary adenoma arising in the left hepatic duct: an unusual tumour in an uncommon location. Eur J Gastroenterol Hepatol 2010; 22(7): 886-888. doi: 10.1097/meg.0b013e3283392a62. 66. Loh A, Kamar S, Dickson GH. Solitary benign papilloma (papillary adenoma) of the cystic duct: a rare cause of biliary colic. Br J Clin Pract 1994; 48(3): 167-168.

67. Dowdy GS Jr, Olin WG, Shelton EL Jr et al. Benign tumors of the extrahepatic ducts. Arch Surg 1962; 85 503-513. doi: 10.1001/archsurg.1962.01310030151024. 68. Allaire GS, Rabin L, Ishak KG et al. Bile duct adenoma. A study of 152 cases. Am J Surg Pathol 1988; 12(9) 708-715. doi: 10.1097/00000478-198809000-00007.

69. Munshi AG, Hassan MA. Common bile duct adenoma: case report and brief review of literature. Surg Laparosc Endosc Percutan Tech 2010; 20(6): 193-194. doi: 10.1097/SLE.0b013e3181f93733.

70. Blot E, Heron F, Cardot F et al. Villous adenoma of the common bile duct. J Clin Gastroenterol 1996; 22(1): 77-79. doi: 10.1097/00004836-199601000-00024

71. Nakanuma Y, Curabo MP, Franceschi S et al. Intrahepatic cholangiocarcinoma. In: Bosman FT, Carnerio F, Hruban $\mathrm{RH}$ et al (eds.). WHO classification of tumours of the digestive system. 4th ed. Lyon: IARC Press 2010: 217-224

72. Ohtsuka M, Shimizu H, Kato A et al. Intraductal papillary neoplasms of the bile duct. Int J Hepatol 2014; 2014 459091. doi: 10.1155/2014/459091.

73. Schlitter AM, Born D, Bettstetter M et al. Intraducta papillary neoplasms of the bile duct: stepwise progression to carcinoma involves common molecular pathways. Mod Pathol 2014; 27(1): 73-86. doi: 10.1038/modpathol.2013.112

74. Zen Y, Sasaki M, Fujii T et al. Different expression patterns of mucin core proteins and cytokeratins during intrahepatic cholangiocarcinogenesis from biliary intraepithelial neoplasia and intraductal papillary neoplasm of the bile duct - an immunohistochemical study of 110 cases of hepatolithiasis. J Hepatol 2006; 44(2) 350-358. doi: 10.1016/j.jhep.2005.09.025.

75. Zen Y, Fujii T, Itatsu K et al. Biliary cystic tumors with bile duct communication: a cystic variant of intraducta papillary neoplasmof the bile duct. Mod Pathol 2006; 19(9): 1243-1254. doi: 10.1038/modpathol.3800643. 76. Rocha FG, Lee $H$, Katabi N et al. Intraductal papillary neoplasm of the bile duct: a biliary equivalent to intraductal papillary mucinous neoplasm of the pancreas? Hepatology 2012; 56(4): 1352-1360. doi: 10.1002/hep.25786.

77. Kim KM, Lee JK, Shin JU et al. Clinicopathologic features of intraductal papillary neoplasm of the bile duct according to histologic subtype. Am J Gastroenterol 2012 107(1): 118-125. doi: 10.1038/ajg.2011.316.

78. Jung G, Park KM, Lee SS et al. Long-termclinical outcome of the surgically resected intraductal papillary neoplasm of the bile duct. J Hepatology 2012; 57(4): 787-793. doi: 10.1016/j.jhep.2012.05.008.

79. Ogawa H, Itoh S, Nagasaka T et al. CT findings of intraductal papillary neoplasm of the bile duct: assessment with multiphase contrast-enhanced examination using multi-detector CT. Clin Radiol 2012; 67(3): 224-231. do 10.1016/j.crad.2011.08.015.

80. Yoon HJ, Kim YK, Jang KT et al. Intraductal papillary neoplasm of the bile ducts: description of MRI and added value of diffusion-weighted MRI. Abdom Imaging 2013 38(5): 1082-1090. doi: 10.1007/s00261-013-9989-4.

81. Yeh T, Tseng J, Chiu C et al. Cholangiographic spectrum of intraductal papillary mucinous neoplasm of the bile ducts. Ann Surg 2006; 244(2): 248-253. doi: 10.1097/01.sla.0000217636.40050.54.

82. Ohtsuka M, Kimura F, Shimizu H et al. Surgical strategy for mucin-producing bile duct tumor. J Hepatobiliary Pancreat Sci; 17(3): 236-240. doi: 10.1007/s00534-0090152-0
83. Saito J, Kitagawa M, Kusanagi $\mathrm{H}$ et al. Granular cell tumor of the common bile duct: a Japanese case. World J Gastroenterol 2012; 18(43): 6324-6327. doi: 10.3748/wjg. v18.i43.6324.

84. Coggins RP. Granular-cell myoblastoma of common bile duct; report of a case with autopsy findings. AMA Arch Pathol 1952; 54(4): 398-402.

85. Mori K, Chano T, Yamamoto K et al. Expression of macrophage inflammatory protein-1alpha in Schwann cell tumors. Neuropathology 2004; 24(2): 131-135.

86. Altavilla G, Brotto M, Busatto $G$ et al. Granular cell tumor of the intrapancreatic common bile duct: one case report and review of the literature. Ultrastruct Pathol 2004; 28(3): 171-176. doi: 10.1080/01913120490475752. 87. Balart LA, Hines C Jr, Mitchell W. Granular cell schwannoma of the extrahepatic biliary system. Am J Gastroenterol 1983; 78(5): 297-300.

88. Weiss SW, Goldblum JR. Benign tumors of peripheral nerves. In: Enzinger and Weiss's soft tissue tumors. Philadelphia: Mosby Elsevier 2008: 878-887.

89. Peyre CG, Wakim M, Mateo R et al. Unusual cases of jaundice secondary to non-neoplastic bile duct obstruction. Am Surg 2004; 70(7): 620-624.

90. Li FY, Cheng JQ, He S et al. Primary neurofibroma of the common bile duct as an unusual cause of obstructive jaundice: a case report. Dig Dis Sci 2005; 50(6): 1166-1168. doi: 10.1007/s10620-005-2726-2

91. De Rosa A, Gomez D, Zaitoun AM et al. Neurofibroma of the bile duct: a rare cause of obstructive jaundice. Ann R Coll Surg Engl 2013; 95(2): e38-e40. doi: 10.1308/00358 $8413 \times 13511609955931$.

92. Mendes Ribeiro HK, Woodham C. CT demonstration of an unusual cause of biliary obstruction in a patient with peripheral neurofibromatosis. Clin Radiol 2000; 55(10): 796-798. doi: 10.1053/crad.2000.0111.

93. Ray S, Das K, Mridha AR et al. Neurofibroma of the common bile duct: a rare cause of obstructive jaundice. Am J Surg 2011; 202(1): e1-e3. doi: 10.1016/j.amjsurg.2010.09.008.

94. Yu RS, Sun JZ. Pancreatic schwannoma: CT findings. Abdom Imaging 2006; 31(1): 103-105. doi: 10.1007/s00261-005-0345-1.

95. Martuza RL, Eldridge R. Neurofibromatosis 2 (bilateral acoustic neurofibromatosis). N Engl J Med 1988; 318(11): 684-688. doi: 10.1056/NEJM198803173181106.

96. Kwon MS, Lee SS, Ahn GH. Schwannomas of the gastrointestinal tract: clinicopathological features of 12 cases including a case of esophageal tumor compared with those of gastrointestinal stromal tumors and leiomyomas of the gastrointestinal tract. Pathol Res Pract 2002; 198(9): 605-613. doi: 10.1078/0344-0338-00309.

97. Jung JH, Joo KR, Chae MJ et al. Extrahepatic biliary schwannomas: a case report. J Korean Med Sci 2007; 22(3): 549-552. doi: 10.3346/jkms.2007.22.3.549.

98. Fonseca GM, Montagnini AL, Rocha Mde S et al. Biliary tract schwannoma: a rare cause of obstructive jaundice in a young patient. World J Gastroenterol 2012; 18(37); 5305-5308. doi: 10.3748/wjg.v18.i37.5305

99. Honjo Y, Kobayashi Y, Nakamura T et al. Extrahepatic biliary schwannoma. Dig Dis Sci 2003; 48(11): 2221-2226. doi: 10.1023/b:ddas.0000004531.97727.66

100. Hou YY, Tan YS, Xu JF et al. Schwannoma of the gastrointestinal tract: a clinicopathological, immunohistochemical and ultrastructural study of 33 cases. Histopathology 2006; 48(5): 536-545. doi: 10.1111/j.13652559.2006.02370.x

101. Fenoglio L, Severini S, Cena P et al. Common bile duct schwannoma: a case report and review of literature. World J Gastroenterol 2007; 13(8): 1275-1278. doi: 10.3748/wjg.v13.i8.1275.

102. Modlin IM, Sandor A. An analysis of 8305 cases of carcinoids tumors. Cancer 1997; 79(4): 813-829. doi: 10.1002/(sici)1097-0142(19970215)79:4<813::aidcncr19>3.0.co;2-2 
103. Gusani NJ, Marsh JW, Nalesnik MA et al. Carcinoid of the extra-hepatic bile duct: a case report with long-term follow up and review of literature. Am Surgeon 2008; 74(1): 87-90

104. Modlin IM, Lye KD, Kidd M. A 5-decade analysis of 13,715 carcinoid tumors. Cancer 2003; 97(4): 934-959. doi: 10.1002/cncr.11105.

105. Capella C, Solcia E, Sobin LH et al. Endocrine tumours of the gallbladder and extrahepatic bile ducts. In: Hamilton R, Aaltonen LA (eds.). Pathology and genetics of tumours of the digestive system. WHO classification of tumours. 3rd ed. Lyon: IARC Press 2000: 214-266.

106. Rindi G, Arnold R, Bosman FT et al. Nomenclature and classification of neuroendocrine neoplasms of the digestive system. In: Bosman FT, Carneiro F, Hruban RH et al (eds.). WHO classification of tumors of the digestive system. 4th ed. Lyon: International Agency for Research on Cancer 2010: 13-14

107. Tsalis K, Parpoudi S, Kyziridis D et al. Klatskin tumors and "Klatskin-mimicking lesions": our 22-year experience. Rev Esp Enferm Dig 2019; 111(2): 121-128. doi: 10.17235/reed.2018.5749/2018.

108. Khuroo S, Rashid A, Bali RS et al. Carcinoid Klatskin tumour: A rare cause of obstructive jaundice. AMJ 2014 7(6): 243-246. doi: 10.4066/AMJ.2014.1934

109. Todoroki T, Sano T, Yamada S et al. Clear cell carcinoid tumor of the distal common bile duct. World J Surg Oncol 2007; 5: 6. doi: 10.1186/1477-7819-5-6.

110. Aronsky D, Z'graggen K, Stauffer E et al. Primary neuroendocrine tumors of the cystic duct. Digestion 1999; 60(5): 493-496. doi: 10.1159/000007696.

111. Brown WM, Henderson JM, Kennedy JC. Carcinoid tumour of the bile duct. A case report and literature review. Am Surg 1990; 56(6): 343-346.

112. Martignoni ME, Friess $H$, LubkeD et al. Study of a primary gastrinoma in the common hepatic duct a case report. Digestion 1999; 60(2): 187-190. doi: 10.1159/000007645.

113. Price TN, Thompson GB, Lewis JT et al. Zollinger-Ellison syndrome due to primary gastrinoma of the extrahepatic biliary tree: three case reports and review of the literature. Endocr Pract 2009; 15(7): 737-749. doi: 10.4158/EP09022.RAR

114. Chamberlain RS, Blumgart LH. Carcinoid tumours of the extrahepatic bile ducts. A rare case of malignant biliary obstruction. Cancer 1999: 86(10): 1959-1965.

115. Nesi G, Lombardi A, Batignani G et al. Well differentiated endocrine tumour of the distal CBD: a case study and literature review. Virchows Arch 2006; 449(1): 104-111. doi: 10.1007/s00428-006-0207-4.

116. Hubert C, Sempoux C, Berquin A et al. Bile duct carcinoids tumors: an uncommon disease but with a good prognosis? Hepatogastroenterology 2005; 52(64): 1042-1047.

117. Malecki EA, Acosta R, Twaddell W et al. Endoscopic diagnosis of a biliary neuroendocrine tumor. Gastrointest Endosc 2009; 70(6): 1275-1276. doi: 10.1016 j.gie.2009.05.021.

118. Tsalis K, Vrakas G, Geroukis T et al. Primary neuroendocrine tumor of the extrahepatic biliary tree mimick ing Klatskin tumor. J Gastrointestin Liver Dis 2010; 19(3) 341-342

119. Maitra A, Krueger JE, Tascilar M et al. Carcinoid tumours of the extrahepatic bile ducts: a study of seven cases. Am J Surg Pathol 2000; 24(11): 1501-1510, doi: 10.1097/00000478-200011000-00005

120. Coffin CM, Watterson J, Priest JR et al. Extrapulmonary inflammatory myofibroblastic tumor (inflammatory pseudotumor). A clinicopathologic and immunohistochemical study of 84 cases. Am J Surg Pathol 1995: 19(8): 859-872. doi: 10.1097/00000478-199508000-00 001.

121. Sasahira N, Kawabe T, Nakamura A et al. Inflammatory pseudotumor of the liver and peripheral eosinophilia in autoimmune pancreatitis. World J Gastroenterol 2005 11(6): 922-925. doi: 10.3748/wjg.v11.66.922.

122. Coffin CM, Humphrey PA, Dehner LP. Extrapulmonary inflammatory myofibroblastic tumor: a clinical and pathological survey. Semin Diagn Pathol 1998; 15(2): 85-101.

123. Nonomura A, Minato $H$, Shimizu K et al. Hepatic hilar inflamatory pseudotumor mimicking cholangiocarcinoma with cholangitis and phlebitis: a variant of primary sclerosing cholangitis? Pathol Res Pract 1997; 193(7): 519-525. doi: 10.1016/S0344-0338(97)80106-9.

124. Amankonah TD, Strom CB, Vierling JM et al. Inflammatory pseudotumor of the liver as the first manifestation of Crohn's disease. Am J Gastroenterol 2001; 96(8): 2520-2522. doi: 10.1111/j.1572-0241.2001.04079x.

125. Knoefel WT, Prenzel KL, Peiper M et al. Klatskint tumors and Klatskin mimicking lesions of the biliary tree. Eur J Surg Oncol 2003; 29(8): 658-661.

126. Corvera CU, Blumgart LH, Darvishian H et al. Clinical and pathologic features of proximal biliary strictures masquerading as hilar cholangiocarcinoma. J Am Coll Surg 2005; 201(6): 862-869. doi: 10.1016/j.jamcollsurg 2005.07.011.

127. Arber DA, Weiss LM, Chang KL. Detection of Epstein-Barr virus in inflammatory pseudotumor. Semin Diagn Pathol 1998; 15(2): 155-160.

128. Yoon KH, Ha HK, Lee JS et al. Inflammatory pseudotumor of the liver in patients with recurrent pyogenic choangitis: CT-histopathologic correlation. Radiology 1999; 211 (2): 373-379. doi: 10.1148/radiology.211.2.r99ma363

129. Someren A. Inflammatory pseudotumor of liver with occlusive phlebitis: report of a case in a child and review of the literature. Am J Clin Pathol 1978; 69(2): 176-181. doi: 10.1093/ajcp/69.2.176

130. Nonaka D, Birbe R, Rosai J. So-called inflammatory myofibroblastic tumour: a proliferative lesion of fibroblastic reticulum cells? Histopathology 2005; 46(6): 604-613. doi: 10.1111/j.1365-2559.2005.02163x

131. Uchida K, Satoi S, Miyoshi H et al. Inflammatory pseudotumors of the pancreas and liver with infiltration of IgG4-positive plasma cells. Intern Med 2007; 46(17): 1409-1412. doi: 10.2169/internalmedicine.46.6430.

132. Tublin ME, Moser AJ, Marsh JW et al. Biliary inflamatory pseudotumor: imaging features in seven patients. AJR Am J Roentgenol 2007; 188(1): 44-48. doi: 10.2214/AJR.05.0985

133. Abu-Wasel B, Eltawil KM, Molinari M. Benign inflammatory pseudotumour mimicking extrahepatic bile duct cholangiocarcinoma in an adult man presenting with painless obstructive jaundice. BMJ Case Rep 2012; 2012: 006514. doi: 10.1136/bcr-2012-006514.

134. Koide H, Sato K, Fukusato T et al. Spontaneous regression of hepatic inflammatory pseudotumor with primary biliary cirrhosis: case report and literature review. World J Gastroenterol 2006; 12(10): 1645-1648. doi 10.3748/wjg.v12.i10.1645

135. Vasiliadis K, Fortounis K, Papavasiliou C et al. Mid common bile duct infl ammatory pseudotumor mimicking cholangiocarcinoma. A case report and literature review. Int J Surg Case Rep 2014; 5(1): 12-15. doi: 10.1016/ j.ijscr.2013.10.017.

136. Hirschfield GM, Karlsen TH, Lindor KD et al. Primary sclerosing cholangitis. Lancet 2013; 382(9904): 1587-1599. doi: 10.1016/50140-6736(13)60096-3.

137. Dave M, Elmunzer BJ, Dwamena BA et al. Primary sclerosing cholangitis: meta-analysis of diagnostic performance of MR cholangiopancreatography. Radiology 2010; 256(2): 387-396. doi: 10.1148/radiol.10091953.

138. Chapman R, Fevery J, Kalloo A et al. Diagnosis and management of primary sclerosing cholangitis. Hepatoogy 2010; 51(2): 660-678. doi: 10.1002/hep.23294.

139. Lindor KD, Kowdley KV, Harrison ME et al. ACG clinical quideline: primary sclerosing cholangitis. Am J Gastroenterol 2015; 110(5): 646-659. doi: 10.1038/ajg.2015.112.
140. Aljiffry M, Renfrew PD, Walsh MJ et al. Analytical review of diagnosis and treatment strategies for dominant bile duct strictures in patients with primary sclerosing cholangitis. HPB (Oxford); 13(2); 79-90. doi: 10.1111/j.1477-2574.2010.00268.x.

141. Broome U, Olsson R, Loof L et al. Natural history and prognostic factors in 305 Swedish patients with primary sclerosing cholangitis. Gut 1996; 38(4): 610-615. doi: 10.1136/gut.38.4.610.

142. Bergquist A, Glaumann H, Persson B et al. Risk factors and clinical presentation of hepatobiliary carcinoma in patients with primary sclerosing cholangitis: a casecontrol study. Hepatology 1998; 27(2): 311-316. doi: 10.1002/hep.510270201.

143. Tischendorf JJ, Kruger M, Trautwein C et al. Cholangioscopic characterization of dominant bile duct stenoses in patients with primary sclerosing cholangitis. Endoscopy 2006; 38(7): 665-669. doi: 10.1055/s-2006925257.

144. Tischendorf JJ, Meier PN, Straßburg CP et al. Characterization and clinical course of hepatobiliary carcinoma in patients with primary sclerosing cholangitis. Scand J Gastroenterol 2006; 41(10): 1227-1234. doi: 10.1080/00365520600633495.

145. Heimbach JK, Gores GJ, Haddock MG et al. Predictors of disease recurrence following neoadjuvant chemoradiotherapy and liver transplantation for unresectable perihilar cholangiocarcinoma. Transplantation 2006; 82(12): 1703-1707. doi: 10.1097/01. tp.0000253551.43583.d1.

146. Lim JH. Oriental cholagiohepatitis: pathologic, clinical, and radiologic features. AJR Am J Roentgenol 1991; 157(1): 1-8. doi: 10.2214/ajr.157.1.2048504

147. Seel DJ, Park YK. Oriental in flectional cholangitis Am J Surg 1983; 146(3): 366-370. doi: 10.1016/00029610(83)90417-8

148. RM S, Koch J, Sandhu JS et al. Recurrent pyogenic cholangitis in Asian immigrants to the United States: natural history and role of therapeutic ERCP. Dig Dis Sci 1997; 42(4): 865-871.

149. Reynolds WR, Brinkman JD, Haney BD et al. Oriental cholangiohepatitis. Mil Med 1994; 159(2): 158-160

150. Tsui WM, Chan Y, Wong C et al. Hepatolithiasis and the syndrome of recurrent pyogenic cholangitis: clinical, radiologic, and pathologic features. Semin Liver Dis 2011; 31(1): 33-48. doi: 10.1055/s-0031-1272833.

151. Park MS, Yu JS, Kim KW et al. Recurrent pyogenic cholangitis: comparison between MR cholangiography and direct cholangiography. Radiology 2001; 220(3): 677-682. doi: 10.1148/radiol.2202001252.

152. Senda Y, Nishio H, Ebata T et al. Hepatolithiasis in the hepatic hilum mimicking hilar cholangiocarcinoma: report of a case. Surg Today 2011; 41(9): 1243-1246. doi: 10.1007/s00595-010-4454-2.

153. Co M, Pang SY, Wong KY et al. Surgical management of recurrent pyogenic cholangitis: 10 years of experience in a tertiary referral centre in Hong Kong. HPB (Oxford) 2014; 16(8): 776-780. doi: 10.1111/hpb.12185.

154. Sarin SK, Bhatia B, Makawane U. Portal biliopathy in extrahepatic portal vein obstruction. Indian J Gastroenterol 1992; 2: A82

155. Sarin SK, Agarwal SR. Extrahepatic portal vein obstruction. Semin Liver Dis 2002; 22(1): 43-58. doi: 10.1055/s-2002-23206

156. Dumortier J, Vaillant $\mathrm{E}$, Boillot $\mathrm{O}$ et al. Diagnosis and treatment of biliary obstruction caused by portal cavernoma. Endoscopy 2003; 35(5): 446-450. doi: 10.1055/s-2003-38779.

157. Vasiliadis K, Engelmann G, Sauer P et al. Right portoovarian $\mathrm{H}$-Shunt for the surgical treatment of symptomatic portal biliopathy: a case report and literature review. HPB Surg 2009; 2009: 152195. doi: 10.1155/2009/152195. 158. Condat B, Vilgrian V, Asselah T et al. Portal cavernoma-associated cholangiopathy: a clinical and MR 
cholangiography coupled with MR portography imaging study. Hepatology 2003; 37(6): 1302-1308. doi: 10.1053/jhep.2003.50232.

159. Khuroo MS, Yattoo GN, Zargar SA et al. Biliary abnormalities associated with extrahepatic portal venous obstruction. Hepatology 1993; 17(5): 807-813.

160. Dhiman RK, Behera A, Chawla YK et al. Portal hypertensive biliopathy. Gut 2007; 56(7): 1001-1008. doi: 10.1136/gut.2006.103606.

161. Shin SM, Kim S, Lee JW et al. Biliary abnormalities associated with portal biliopathy: evaluation on MR cholangiography. Am J Roentgenol 2007; 188(4): 341-347. doi: 10.2214/AJR.05.1649.

162. Bayrakatar Y, Balkanci F, Kayhan B et al. Bile duct varices or "pseudocholangiocarcinoma sign" in portal hypertension due to cavernous transformation of the portal vein. Am J Gastroenterol 1992; 87(12): 1801-1806.

163. Mirizzi PL. Sindrome del conducto hepatico. J Int Chir 1948; 8: 731-737.

164. Csendes A, Diaz JC, Burdiles P et al. Mirizzi syndrome and cholecystobiliary fistula: a unifying classi fi cation. Br J Surg 1989: 76(11): 1139-1143.

165. Johnson LW, Sehon JK, Lee WC et al. Mirizzi's syndrome: experience from a multi-institutional review. Am Surg 2001; 67(1): 11-14

166. Lai EC, Lau WY. Mirizzi syndrome: history, present and future development. ANZ J Surg 2006; 76(4): 251-257. doi: 10.1111/j.1445-2197.2006.03690.x

167. Kumar A, Senthil G, Prakash A et al. Mirizzi's syndrome: lessons learnt from 169 patients at a single center Korean J Hepatobiliary Pancreat Surg 2016; 20(1): 17-22. doi: 10.14701/kjhbps.2016.20.1.17

168. Prasad TL, Kumar A, Sikora SS et al. Mirizzi syndrome and gallbladder cancer. J Hepatobiliary Pancreat Surg 2006: 13(4): 323-326. doi: 10.1007/s00534-005-1072-2.

169. Kamisawa T, Egawa N, Nakajima H. Autoimmune pancreatitis is a systemic autoimmune disease. Am J Gastroenterol 2003; 98(12): 2811-2812. doi: 10.1111/j.1572 0241.2003.08758.x

170. Kamisawa T, Funata N, Hayashi Y et al. A new clinicopathological entity of IgG4-related autoimmune disease. J Gastroenterolology 2003; 38(10): 982-984. doi: 10.1007/s00535-003-1175-y.

171. Okazaki K, Uchida K, Koyabu M et al. Recent advances in the concept and diagnosis of autoimmune pancreatitis and IgG4-related disease. J Gastroenterology 2011; 46(3): 277-288. doi: 10.1007/s00535-011-0386-x.

172. Kamisawa T, Okamoto A. IgG4-related sclerosing disease. World J Gastroenterol 2008; 14(25): 3948-3955. doi: 10.3748/wjg.14.3948.

173. Kanno A, Nishimori I, Masamune A et al. Nationwide epidemiological survey of autoimmune pancreatitis in Japan. Pancreas 2012; 41(6): 835-839. doi: 10.1097/MPA.0b013e3182480c99.

174. Cheuk W, Chan JKC. IgG4-related sclerosing disease: a critical appraisal of an evolving clinicopathologic entity. Adv Anat Pathol 2010; 17(5): 303-332. doi: 10.1097/PAP.0b013e3181ee63ce.
175. Stromnes IM, Cerretti LM, Liggitt D et al. Differentia regulation of central nervous system autoimmunity by TH1 and TH17 cells. Nat Med 2008; 14(3): 337-342. do: 10.1038/nm1715

176. Zen Y, Fujii T, Harada K et al. Th2 and regulatory immune reactions are increased in immunoglobin G4-related sclerosing pancreatitis and cholangitis. Hepatology 2007: 45(6): 1538-1546. doi: 10.1002/hep.21697.

177. Shimosegawa T, Chari ST, Frulloni L et al. International consensus diagnostic criteria for autoimmune pancreatitis: guidelines of the international association of pancreatology. Pancreas 2011; 40(3): 352-358. doi: 10.1097/MPA.0b013e3182142fd2.

178. Chari ST, Smyrk TC, Levy MJ et al. Diagnosis of au toimmune pancreatitis: the Mayo Clinic experience. Clin Gastroenterol Hepatol 2006; 4(8): 1010-1016. doi: 10.1016/j.cgh.2006.05.017.

179. Deshpande V, Zen Y, Chan JK et al. Consensus statement on the pathology of IgG4-related disease. Mod Pathol 2012; 25(9): 1181-1192. doi: 10.1038/mod pathol.2012.72.

180. Ghazale A, Chari ST, Zhang L et al. Immunoglobulin G4-associated cholangitis: clinical profile and response to therapy. Gastroenterol 2008; 134(3): 706-715. doi: 10.1053/j.gastro.2007.12.009

181. Alderlieste $Y A$, van den Elzen BD, Rauws EA et al. Immunoglobulin G4-associated cholangitis: one variant of immunoglobulin G4-related systemic disease. Digestion 2009; 79(4): 220-228. doi: 10.1159/000213364.

182. Nishino T, Toki F, Oyama H et al. Biliary tract involvement in autoimmune pancreatitis. Pancreas 2005; 30(1): 76-82.

183. Joshi D, Webster GJ. Immunoglobulin G4-related sclerosing cholangitis. Hepatology 2015; 61(4): 1432-1434. doi: 10.1002/hep.27411.

184. Ohara H, Okazaki K, Tsubouchi H et al. Clinical diagnostic criteria of lgG4-related sclerosing cholangitis 2012 J Hepatobiliary Pancreat Sci 2012; 19(5): 536-542. doi: 10.1007/s00534-012-0521-y

185. Yang DH, Kim KW, Kim TK et al. Autoimmune pancreatitis: radiologic findings in 20 patients. Abdom Imaging 2006; 31 (1): 94-102. doi: 10.1007/s00261-005-0047-8. 186. Webster GJ, Pereira SP, Chapman RW. Autoimmune pancreatitis/lgG4-associated cholangitis and primary sclerosing cholangitis - overlapping or separate diseases? J Hepatol 2009; 51(2): 398-402. doi: 10.1016/ j.jhep.2009.04.010

187. Chung DT, Tang CN, Lai EC et al. Immunoglobulin G4-associated sclerosing cholangitis mimicking cholangiocarcinoma. Hong Kong Med J 2010; 16(2): $149-502$

188. Lytras D, Kalaitzakis E, Webster GJ et al. Cholangiocarcinoma or IgG4- associated cholangitis: how feasible it is to avoid unnecessary surgical interventions? Ann Surg 2012; 256(6): 1059-1067. doi: 10.1097/SLA.0b013e318253 $3 \mathrm{a} 0 \mathrm{a}$

189. Hussain R, Poindexter RW, Ottesen EA. Control of allergic reactivity in human filariasis. Predominant localiza- tion of blocking antibody to the IgG4 subclass. J Immunol 1992; 148(9): 2731-2737.

190. Zen Y, Nakanuma Y. IgG4 cholangiopathy. Int J Hepatol 2012; 2012: 472376. doi: 10.1155/2012/472376.

191. Senthil Kumar MP, Marudanayagam R. Klatskin-like lesions. HPB Surg 2012; 2012: 107519. doi: 10.1155/2012/107519.

192. Stone JH, Zen Y, Deshpande V. IgG4-related disease. N Engl J Med 2012; 366(6): 539-551. doi: 10.1056/NEJMra1104650.

193. Ghazale A, Chari ST, Zhang L et al. Immunoglobulin G4-associated cholangitis: clinical profile and response to therapy. Gastroenterology 2008; 134(3): 706-715. doi: 10.1053/j.gastro.2007.12.009.

194. Cox CE, Davis-Allen A, Judson MA. Sarcoidosis. Med Clin North Am 2005; 89(4): 817-828. doi: 10.1016/ j.mcna.2005.02.006

195. Cremers J, Drent M, Driessen A et al. Liver-test abnormalities in sarcoidosis. Eur J Gastroenterol Hepatol 2012: 24(1): 17-24. doi: 10.1097/MEG.0b013e32834c7b71

196. Judson MA Extrapulmonary sarcoidosis. Semin Respir Crit Care Med 2007; 28(1): 83-101. doi: 10.1055/s-2007-970335.

197. Mueller S, Boehme MW, Hofmann WJ et al. Extrapulmonary sarcoidosis primarily diagnosed in the liver. Scand J Gastroenterol 2000; 35(9): 1003-1008. doi: 10.1080/003655200750023110

198. Pungpapong S, Steers JL, Wallace MB et al. Hepatobiliary sarcoidosis mimicking Klatskin's cholangiocarcinoma. Gastrointest Endosc 2006; 64(1): 124-125. doi: 10.1016/j.gie.2006.01.033

199. Ishak KG. Sarcoidosis of the liver and bile ducts. Mayo Clin Proc 1998; 73(5): 467-472. doi: 10.1016/S00256196(11)63733-6.

200. Alam I, Levenson SD, Ferrell LD et al. Diffuse intrahepatic biliary strictures in sarcoidosis resembling sclerosing cholangitis. Case report and review of the literature. Dig Dis Sci 1997; 42(6): 1295-1301. doi: 10.1023/a:1018874612166.

201. Harder H, Büchler MW, Fröhlich B et al. Extrapulmonary sarcoidosis of liver and pancreas: a case report and review of literature. World J Gastroenterol 2007; 13(17): 2504-2509. doi: 10.3748/wjg.v13.i17.2504

202. Kwon AH, Matsui Y, Uemura Y. Surgical procedures and histopathologic findings for patients with xanthogranulomatous cholecystitis. J Am Coll Surg 2004: 199(2): 204-210. doi: 10.1016/j.jamcollsurg.2004.03.018. 203. Dixit VK, Prakash A, Gupta A et al. Xanthogranulomatous cholecystitis. Dig Dis Sci 1998; 43(5): 940-942. doi: 10.1023/a:1018802028193.

204. Guzman-Valdivia G. Xanthogranulomatous cholecystitis: 15 years' experience. World J Surg 2004; 28(3): 254-257. doi: 10.1007/s00268-003-7161-y.

205. Krishna RP, Kumar A, Singh RK et al. Xanthogranulomatous inflammatory strictures of extrahepatic biliary tract: presentation and surgical management. J Gastrointest Surg 2008: 12(5): 836-841. doi: 10.1007/s11605-0080478-y. 